\title{
UN EJEMPLO DE REACCIONARISMO CATÓLICO CONTRA LA HETERODOXIA ILUSTRADA EN LA ESPAÑA DE FINALES DEL XVIII: LA NOVELA EL IMPIOO POR VANIDAD DEL PADRE MARTÍNEZ COLOMER
}

\author{
An Axample of Catholic Reactionarism Against \\ Enlightened Heterodoxy in the Spain at the End \\ of the 18th Century: Father Martinez Colomer's Novel \\ El impío por vanidad
}

\author{
Javier MUÑOZ DE MORALES GALIANA \\ Universidad de Cádiz \\ javier.munozdemorales@uca.es
}

Fecha de recepción: 16/07/2019

Fecha de aceptación definitiva: 07/11/2019

\begin{abstract}
RESUMEN: El padre Vicente Martínez Colomer es uno de los novelistas españoles de finales del XVIII mejor valorados por la crítica, sobre todo por su novela $E l$ Valdemaro. No obstante, otra de sus narraciones, El impío por vanidad, es también interesante en tanto que supone un ejemplo muy evidente de la ideología más habitual entre los intelectuales más reaccionarios de la época. Por aquel entonces, buena parte de la filosofía ilustrada comenzaba a atacar algunos de los principales dogmas del catolicismo; la novela El impío por vanidad vendría a ser un intento de reaccionar contra la vertiente más heterodoxa de la Ilustración. Para ello, el autor se sirve del sentimentalismo típico de la narrativa de la época utilizado, de una manera más bien sensacionalista, con el objeto de provocar espanto en el lector hacia las nuevas corrientes de pensamiento.
\end{abstract}

Palabras clave: Vicente Martínez Colomer; novela española; siglo XVIII; Ilustración; catolicismo; Jean-Jacques Rousseau. 
ABSTRACT: Father Vicente Martínez Colomer is one of the novelists at the end of XVIII most ratted by the critics, specially cause his novel El Valdemaro. By the way, another of his narrations, El impio por vanidad, is also interesting as long as it supposes an example quite evident of the most habitual ideology among the most reactionaries intellectuals of that time. By then, an important part of the enlightenment's philosophy had started to attack some of the main dogmas of the Catholicism; the novel El impio por vanidad would come to be an attempt to react against the most heterodox side of the Enlightenment. For it, the author uses the sentimentalism typical of these years, used by a sensationalism way, with the object to cause frightfulness towards that new points of view.

Key words: Vicente Martínez Colomer; Spanish novel; eighteen century; Enlightenment; Catholicism; Jean-Jacques Rousseau.

1. El papel de la nOVela en el XViII español y el Caso de Vicente Martínez COLOMER

Es bien sabido que en el siglo XVIII la novela española tenía importantes dificultades para su desarrollo, esencialmente porque no era un género que se soliese tomar en serio al no ser contemplado en las poéticas neoclásicas ${ }^{1}$. Por ello es lógico que habitualmente sirviese tan solo para la difusión de propaganda ideológica. Narraciones como el Fray Gerundio o el Eusebio suelen ser las más representativas de ese siglo, y están caracterizadas por subordinar en todo momento lo literario al mensaje moral. No se puede decir, por ello, que el sentimentalismo sea lo más destacable de esas obras: predomina, más bien, una frialdad racionalista propia de la Ilustración. No obstante, dentro del contexto de la España del XVIII hubo, sobre todo en los últimos años, otros novelistas que supieron ver en lo emotivo un recurso para dar mayor fuerza a las ideas divulgadas en sus obras.

Por lo general, suele asociarse la acentuación de las pasiones a finales del XVIII con la incipiente llegada del Romanticismo. No obstante, estos dos fenómenos no tienen por qué estar necesariamente ligados. Hubo numerosos ilustrados, sobre todo en el ámbito europeo, que llegaron a teorizar sobre el valor artístico de las emociones intensas sin necesidad de adentrarse en la estética romántica. El tratado De lo sublime y de lo bello (1757) de Edmund Burke quizá sea una de las obras más representativas de esto, por elogiar el arte capaz de provocar las emociones más intensas. Y también hubo quien teorizó, en esa línea, sobre el género novelesco: un claro ejemplo es el marqués de Sade y sus Ideas sobre la novela, que no vieron la luz hasta 1800, si bien en ellas se mostraba un gran aprecio hacia buena parte de la narrativa dieciochesca sobre todo por su faceta más estremecedora. Sade propone a Richardson como el modelo fundamental a seguir por todo

1. Álvarez Barrientos, Joaquín. La novela del siglo XVIII. 1. a edición. Madrid: Júcar, 1991, p. 11. 
buen novelista; destaca, en concreto, su Clarisa, por suponer un sentimentalismo desgarrador en tanto que la virtud acaba siendo humillada mientras el vicio triunfa. Esa novela narraba, de hecho, la historia de la mujer que da título a la obra, una muchacha inocente que es engañada, secuestrada y violada por un orgulloso libertino llamado Lovelace.

Aunque el texto de Sade no fue conocido por la mayoría de los autores que novelizaron en España, sí que lo fue el de Richardson². Varias novelas del XVIII español están vertebradas por ideas muy similares a las que configuran la Clarisa, en tanto que suele haber, casi siempre, una emotividad espeluznante, motivada la mayor parte de las veces también por la destrucción de la virtud. Tal es el caso de algunas de las novelas de Ignacio García Malo, como Lisandro y Rosaura (1787), La desventurada Margarita (1787) o El brigadier y Carlota (1792)3; todas ellas están protagonizadas por mujeres que, a pesar de su carácter virtuoso y ejemplar, sufren numerosos maltratos y humillaciones. Esas obras son, por encima de todo, novelas cuyo principal fin es proporcionar una enseñanza al lector; el elemento pasional no tiene más objetivo que el de intensificar el mensaje ético transmitido, algo muy propio de una época en la que la literatura se veía como instrumento para la educación de los lectores.

La novela de la que nos ocupamos en este artículo, El impio por vanidad de Vicente Martínez Colomer, es en ese sentido muy similar a las de García Malo, pero con un trasfondo ideológico diferente. Las de este último moralizaban, pero sobre cuestiones más bien generales, casi siempre de carácter sentimental, como la libre elección del cónyuge, la tiranía ejercida por los padres o los maltratos diversos dados en los matrimonios disfuncionales; aunque esos temas solían ser tratados en muchas otras obras del XVIII, la postura de García Malo resultaba especialmente progresista en tanto que muestra un claro afán por denunciar las injusticias dadas a partir de los abusos del poder.

No obstante, dentro de toda la literatura dieciochesca con afán didáctico podemos ver muchos casos de obras con ideologías prácticamente opuestas. Los ilustrados más heterodoxos, como Rousseau o Voltaire, generaban especial polémica entre los sectores más reaccionarios y conservadores de la sociedad. El clero miraba con muy malos ojos que algunos de los principales dogmas de la Iglesia empezasen a ser tan duramente atacados; en España, país en el que todavía continuaba la Inquisición, se dieron extremos tan radicales como la prohibición de las

2. La Clarisa se publicó por primera vez en España entre 1794 y 1795 , con el título de Clara Harlowe; posteriormente, llegaría a tener un total de tres reediciones hasta 1846 ( $c f$. MonTESINOs, José F. Introducción a una historia de la novela en España en el siglo XIX. $1 .^{a}$ edición [1. ${ }^{a}$ edición original: 1955]. Madrid: Castalia, 1982, p. 233).

3. Esas tres obras forman parte de la colección de novelas Voz de la naturaleza, que comprendía un total de doce títulos, todos ellos originales de García Malo. En 1995 se editó una antología, a cargo de Guillermo Carnero, que incluía siete de las doce novelas de la colección, entre ellas las que acabamos de mencionar. 
obras de Rousseau en su totalidad ${ }^{4}$. Pero los eclesiásticos no solo se sirvieron de la censura para contraatacar a la heterodoxia y a la irreligiosidad; durante estos años empezó a difundirse «una literatura que presenta a la Ilustración como una conspiración de las fuerzas del Mal contra el orden jerárquico querido por Dios», obras en las que generalmente «los filósofos forman una conjura contra el Bien, de que sus jefes son Voltaire y Rousseau ".

El padre Andrés Merino de Jesucristo, por ejemplo, es un caso bastante representativo de este fenómeno ${ }^{6}$; con ese fin escribió una utopía contraria a las ideas de la Ilustración, el Tratado sobre la monarquía columbina, inédita, y una novela pseudohistórica, La mujer feliz (1786), en la que mostraba también una mentalidad especialmente reaccionaria. Un perfil muy parecido se puede intuir en fray Vicente Martínez Colomer a partir de la lectura de sus obras. La crítica empezó a darle importancia a este otro autor sobre todo a partir de que se reeditara en 1985 una de sus novelas, El Valdemaro (1792), con una edición a cargo de Guillermo Carnero en la que se le presentaba como un precursor del Romanticismo injustamente olvidado ${ }^{7}$. La narración, de carácter histórico, estaba llena de aventuras y elementos sobrenaturales, pero mantenía en todo momento una fuerte preocupación por moralizar en favor de la ortodoxia católica.

Hasta el momento todavía no ha sido considerado, pero tenemos sólidas razones por las que creer que una de las principales influencias de Martínez Colomer fue una novela portuguesa bastante conocida en la España de la época: El hombre feliz, independiente del mundo y de la fortuna, del padre Teodoro de Almeida. Es una novela didáctica, escrita también desde el punto de vista de la ortodoxia católica, y está encuadrada dentro del prerromanticismo portugués ${ }^{8}$. En nuestro país apareció en 1783, y tuvo un éxito considerable?. Ambientada también en la Edad Media, narraba una serie de aventuras en las que la religión era

4. VÁZQuEZ, Lydia. "Introducción». En RousseAu, Jean-Jacques. La nueva Eloísa. 1. a edición [1. ${ }^{a}$ edición original: 1813]. Madrid: Cátedra, 2013, p. 73.

5. Herrero, Javier. Los orígenes del pensamiento reaccionario español. 1. ${ }^{\text {a }}$ edición. Madrid: Alianza, 1988, p. 33.

6. Para más información sobre el padre Andrés Merino, véanse los siguientes trabajos: ÁLVAREZ De Miranda, Pedro. "La primitiva versión (1814) del Don Papis de Bobadilla de Rafael José de Crespo". En CARNERO, Guillermo; LóPEZ, Ignacio Javier y RuBIO, Enrique. Ideas en sus paisajes. Homenaje al profesor Russell P. Sebold. 1. ${ }^{a}$ edición. Alicante: Universidad, 1999, pp. 63-70; PALACios FernándeZ, Emilio. "El padre Andrés Merino de Jesucristo y la cultura española del siglo XVIII. Boletín de la Real Sociedad Bascongada de Amigos del País, 1991, 47 (1), pp. 3-42; y Álvarez Barrientos. Op. cit., pp. 232-234.

7. CARNERO, Guillermo. "Introducción». En MARTínez COLOMER, Vicente. El Valdemaro. 1. ${ }^{a}$ edición [1. ${ }^{a}$ edición original: 1792]. Alicante: Instituto de Estudios Juan Gil Albert, 1985, pp. 16-17.

8. OGANDO GONZÁLEZ, Iolanda. "La literatura portuguesa del siglo XVIII: ostentación, razón, modernidad». En Fernández García, María Jesús (coord.). Historia de la literatura portuguesa. $1 .^{a}$ edición. Mérida: Junta de Extremadura, 2011, p. 189.

9. Álvarez BARrientos (op. cit., p. 234) menciona que esta novela tuvo «numerosas reediciones»; tanto fue así que, por ejemplo, aparece mencionada treinta y tres años después en El Periquillo Sarniento, de Fernández de Lizardi, en un pasaje en el que al protagonista se la mandan en la escuela 
siempre la respuesta a cualquier angustia del ser humano, y a pesar de su carácter pseudohistórico en ella se puede encontrar alguna diatriba contra las ideas de los filósofos ilustrados ${ }^{10}$. Precisamente este motivo, junto a su entusiasmo frente a la religión, sea lo que fundamentalmente llevara a Martínez Colomer a tener en cuenta esta obra como referente.

Es en El Valdemaro, sobre todo, donde más se aprecia la influencia de $E l$ hombre feliz. Las dos novelas evocan con nostalgia una Edad Media idílica, en la que la fe católica podía con todo; en las dos hay, precisamente, personajes que dudan de su fe y que intentan ser reconducidos mediante el sermón religioso como forma de acabar con todos los males; y en las dos hay, a su vez, aventuras y elementos sobrenaturales que vienen a evidenciar, sobre todo, el triunfo de Dios sobre cualquier clase de maldad.

Pero, aunque El Valdemaro fue su novela más conocida, no fue la única que Martínez Colomer compuso. Así, en el 2000 apareció una edición crítica de su primera novela, compuesta en 1784, pero que había quedado inédita; nos referimos a Los trabajos de Narciso y Filomela. Como se puede deducir, se trata de una imitación del Persiles de Cervantes, actualizando la sensibilidad a su época, pero intentando resucitar la rectitud católica propia del siglo XVII. Aparte, también publicó, en 1790, una serie de novelitas de índole moral bajo el seudónimo de Francisca Boronat y Borja, la Nueva colección de novelas ejemplares: El petimetre pedante, El hallazgo de Alejandrina, La Narcisa y La Dorinda; en ellas mantiene, nuevamente, una visión del mundo de lo más tradicional como solución a cualquier problema del ser humano. En 1792 apareció la que sería su obra más famosa, El Valdemaro; tres años después publicó también la novela de la que aquí nos ocupamos $^{11}$ : El impío por vanidad, una obra en la que, como veremos, la crítica hacia la heterodoxia ilustrada adquiere una importancia capital. Esta obra se reedita, en 1804, junto a la Nueva colección de novelas ejemplares, en una refundición titulada Novelas morales ${ }^{12}$. Su última novela es Sor Inés, publicada en 1815, y también en torno a una temática religiosa.

Creemos de interés prestar especial atención a El impio por vanidad para poder analizar la faceta más reaccionaria de Martínez Colomer. La crítica, por lo

como lectura obligatoria (FernáNDEZ DE LIZARDI, José Joaquín. El Periquillo Sarniento. 1. ${ }^{a}$ edición [1. ${ }^{a}$ edición original: 1816]. Madrid: Cátedra, 1997, p. 135).

10. Almeida, Teodoro de. El hombre feliz. 1. ${ }^{a}$ edición [1. ${ }^{a}$ edición en castellano: 1783]. Madrid: Yatay, 1998, pp. 80-81.

11. Hay ciertos indicios de que tal vez la novela se publicase originalmente en 1792; CARNERO menciona a varios autores que la fechan en ese año (op. cit., p. 24). No obstante, no se ha localizado ningún ejemplar de esa supuesta primera edición; además, en 2009 Carnero volvió a publicar el trabajo de 1985 en un volumen recopilatorio, con algunas modificaciones; entre ellas, que El impío por vanidad es fechado únicamente en 1795 sin mencionar la posibilidad de una edición anterior (CARNERO, Guillermo. Estudios sobre narrativa y otros temas dieciochescos. 1. ${ }^{a}$ edición. Salamanca: Universidad de Salamanca, 2009, p. 141).

12. CARnero. Op. cit., p. 141. 
general, lo ha estudiado sobre todo como uno de los más importantes renovadores literarios del género novelesco en el XVIII español; quizá El impío no sea su mejor novela, pero en ella su ideología puede apreciarse con especial nitidez ${ }^{13}$. Analizarla puede suponer, por ello, un acercamiento a las motivaciones de los sectores más reaccionarios de la población, así como a las estrategias propagandísticas que utilizaron para desacreditar la filosofía más heterodoxa de su tiempo.

\section{EL IMPÍO POR VANIDAD: PRESENTACIÓN DE LA NOVELA Y ARGUMENTO}

La edición que hemos manejado es la de 1795, impresa en Valencia, en la imprenta de Josef Estevan; el ejemplar que hemos utilizado es el que se puede localizar en la biblioteca de la Universidad de Valencia (VIII + 158 páginas en octava). Todas las citas de El impío reproducidas en el presente artículo provienen de esa misma edición. Hemos modernizado las grafías en cada una de ellas.

Aparte de Carnero, que explica brevemente su contenido ${ }^{14}$, no tenemos noticia de más investigadores que hayan reparado demasiado en El impio por vanidad. La intención del autor, como ya hemos dicho, es fácilmente deducible: echar por tierra toda la filosofía ilustrada que pudiese cuestionar total o parcialmente la moral católica. De esto no hay lugar a dudas porque se revela en el mismo prólogo; en él, el autor declara que escribe en el género novelesco para ofrecer una alternativa más católica a los lectores de esta clase de textos, habitualmente tachados de inmoralidad; en el caso concreto de esta novela, especifica que su objetivo es "hacer que abran los ojos esos preciados de bellos espíritus, que por haber leído algunas sátiras, y otras tantas bufonadas sacrílegas contra nuestra Santa Fe en algunos papeles proscriptos, y por haber oído decir que hay una nueva casta de filósofos, inventores de doctrinas opuestas a los más sagrados dogmas de nuestra Religión Augusta, se han hecho de su bando» (s. p.).

Para lograr este propósito, Martínez Colomer nos presenta una historia articulada en torno a dos personajes: Eugenio, un muchacho cristiano que representa toda la bondad de la Iglesia; y don Paco María de los Dolores, marqués de Viruenga, un sujeto completamente depravado por su contacto con las ideas ilustradas que cuestionaban el dogma católico. La narración de la novela es mínima; no hay mucho más aparte de una discusión acalorada entre los dos personajes sobre la religión, uno atacándola y otro defendiéndola. Después de semejante debate de índole teológica, el autor decide introducir el elemento melodramático para

13. En el prólogo a las Novelas morales en las que El impío se incluye, Martínez Colomer admitirá que estas novelas no poseen demasiado valor estético, pero sí ético: «Estas novelas no son de aquellas que arrebatan; pero pueden servir para una recreación honesta y que tal vez no carecerá de utilidad» (MARTíNEZ Colomer, Vicente. Novelas morales. 2. ${ }^{\mathrm{a}}$ edición [1. ${ }^{\mathrm{a}}$ edición, sin El impío por vanidad: 1790]. Valencia: Benito Monfort, s. p.).

14. Op. cit., pp. 145-146. 
demostrar lo abominable que es la vida más allá de la luz de Dios. De esta guisa, se suceden muy precipitadamente una serie de eventos trágicos en torno a don Paco que vienen a manifestar lo depravado de su conducta. La novela concluye con el marqués muriendo en unas condiciones terribles, mientras Eugenio es feliz llevando junto a su esposa una vida dentro de la más absoluta rectitud cristiana.

Aunque ese sea, básicamente, todo el contenido de la novela, para poder comprenderla mejor será necesario especificar cómo son presentados los acontecimientos al lector, atendiendo a ciertas peculiaridades relativas al punto de vista. Don Paco, marqués de Viruenga, es, sin duda, el protagonista de la novela; el argumento gira en torno a él, y es también a él a quien hace referencia el sintagma nominal del título; él es, en definitiva, «el impío por vanidad». No obstante, la voz del autor es en todo momento Eugenio; desde el comienzo de la novela se pretende que nos sintamos cercanos a este último, precisamente para despreciar luego con más razón a su oponente.

Lo primero que se menciona en la novela es, de hecho, un viaje que Eugenio llevó a cabo por Europa en compañía de su preceptor Teodoro, experiencia que le sirvió bastante para aprender sobre el mundo y sobre la vida (pp. 1-4); el trayecto como tal no se narra, sino que simplemente queda aludido. Después tiene lugar el reencuentro con sus padres a la vuelta del periplo, momento en el que les cuenta ciertos detalles de sus andanzas (pp. 4-10); tras esto la familia se reúne con un amigo, don Máximo, momento en el que aparece, por primera vez, don Paco (pp. 11-13). La forma de vestir y el comportamiento de este último hace que Eugenio comience a formarse una primera impresión no demasiado favorable (pp. 13-20), impresión que se confirma en una discusión sobre estética y moral que tienen al llegar a una librería (pp. 20-27). Entran después en una sala llena de cuadros alegóricos que son descritos con detalle (pp. 28-33); tras esto, el marqués deja caer ciertos comentarios mordaces en los que demuestra un evidente desprecio hacia la austeridad cristiana (pp. 33-34). Don Paco se despide y se aleja de allí con don Máximo, momento en el que aprovecha la ausencia de Eugenio para criticarlo y burlarse de él a sus espaldas a causa de sus valores cristianos (pp. 35-40). La retahíla de burlas queda interrumpida en el momento en el que se encuentran con Carmela, la hija de don Máximo, con quien el marqués muestra un comportamiento notablemente galante, atrevido y seductor; don Máximo, cegado por su amistad con don Paco, no llega a ver nada sospechoso en esto (pp. 40-43). Se encuentran por la calle con Eugenio y Teodoro, y el punto de vista pasa de nuevo a estos últimos, quienes también empiezan a criticar al marqués por su actitud sibarítica, refinada y poco cristiana (pp. 44-49). Al día siguiente, la familia de don Máximo tiene un nuevo encuentro con la de Eugenio; en ese encuentro se describe a la hermana de Carmela, Casilda, caracterizada por un recato cristiano que la vuelve totalmente inmune a los galanteos del marqués (pp. 49-56).

Don Paco insiste en cortejar a Carmela con descaro, lo cual empieza a poner a prueba la paciencia de Eugenio; llega un momento en el que este ya no puede más y se enzarza en una acalorada y larga discusión con el marqués, en la que 
este último profiere todo tipo de blasfemias (pp. 56-102). El marqués acaba largándose de allí, desapareciendo sin dejar rastro; Carmela entonces rompe a llorar y admite que se encuentra perdidamente enamorada de don Paco (pp. 102-114). Eugenio regresa de buscar al marqués, y, aunque no logra dar con él, sí que trae noticias relevantes al respecto: descubre que ese supuesto "marqués» es en realidad un aventurero libertino que vive separado de su mujer y que va de un lado a otro cambiando de identidad (pp. 115-124).

Eugenio se retira a dormir e, incapaz de conciliar el sueño, se pone a mirar por la ventana; casualmente llega a contemplar una truculenta escena en la que Carmela se intenta suicidar; su muerte es evitada en el último momento por su hermana Casilda (pp. 125-128). Eugenio interviene en ese momento, y las hermanas le cuentan toda la verdad: don Paco había logrado burlar el honor de Carmela mediante seducciones y ardides, y al darse ella cuenta del carácter blasfemo de este y de que había desaparecido sin intención de volver, su dolor es tal que llega hasta el intento de suicidio (pp. 128-138). Aparece entonces don Máximo con nuevas noticias sobre el paradero del marqués, quien había sido agredido mortalmente por unos embozados que habían tenido problemas con él por cuestiones de mujeres (pp. 139-140). Todos acuden al hospital en el que yacía, herido de muerte, el marqués, y Eugenio asiste de primera mano a una escena notablemente siniestra; a pesar de estar a punto de morir, don Paco insiste en llevar hasta el final su impiedad y abandonar el mundo sin ningún tipo de confesión (pp. 140-146). El autor introduce, por boca de Eugenio, la moraleja de la historia; y no solo carga contra el marqués por ser un blasfemo, sino también contra don Máximo por consentirlo (pp. 146-155). La novela concluye con Carmela metiéndose a monja después de recobrarse de una depresión -y de un aborto- ${ }^{15}$ con la ayuda de Eugenio y su madre, y con el matrimonio feliz de Eugenio con la casta Casilda (pp. 155-158).

\section{LAS DICOTOMÍAS RELIGIOSO/IRRELIGIOSO Y FELIZ/INFELIZ}

Si atendemos a este resumen de los acontecimientos, veremos que en un principio don Paco se nos muestra como un tipo afrancesado, prepotente y algo ridículo; poco a poco vamos viendo que, aparte de eso, es un completo ateo que rechaza los dogmas más sagrados; no es hasta el final, sin embargo, cuando descubrimos hasta qué punto estamos hablando de una persona totalmente degenerada y corrupta moralmente. El ir revelando de forma progresiva la maldad del protagonista es uno de los principales recursos del autor para acentuar el

15. Entiéndase, un aborto natural: el autor especifica que «una superior providencia le eximió en breve de este cuidado" (p. 153), porque tuvo un "accidente furioso" (p. 155), y "por providencia particular del cielo, nadie pudo traslucir jamás una mancha que hubiera servido siempre de negro oprobio a la incauta Carmela» (p. 157). 
sentimentalismo, tal como ocurría, por ejemplo, en la Clarisa de Richardson ${ }^{16}$. Si desde el primer momento se caracterizase a don Paco como un depravado, no habría sorpresa posible; sin embargo, el patetismo logrado es mayor al desvelarlo al final de la novela.

Al lector, en un primer momento, no se le da ningún indicio de que don Paco pueda llegar a tales extremos con su conducta. En las primeras páginas puede recordar, incluso, a algunos retratos caricaturescos y francófobos que proliferaban en la literatura de la época. Carnero, de hecho, llega incluso a comparar esta novela con El petimetre pedante ${ }^{17}$, una obra anterior de Martínez Colomer ${ }^{18}$. Álvarez Barrientos ofrece una perspectiva similar al incluirla en una corriente de obras del XVIII caracterizadas por su costumbrismo fuertemente francófobo, junto a obras como las Adiciones a la bistoria de don Quijote de Jacinto María Delgado (1786) ${ }^{19}$ o El petimetre pedante $(1790)^{20}$. En esas novelas aparecían sujetos grotescos y ridículos por ser afrancesados, cuyo objetivo era provocar la risa del lector más que el espanto. Esto solo se aplica a las primeras páginas de El impío porvanidad; posteriormente, y sobre todo en las escenas finales, lo ridículo es abandonado en favor de lo macabro.

16. En esa novela, Lovelace está fuertemente caracterizado como un sujeto peligroso e inmoral; no obstante, eso no se revela directamente, sino poco a poco, a lo largo de un notable número de cartas en las que el lector se va percatando paulatinamente de las taras morales del personaje.

17. Op. cit., pp. 143-144

18. El estereotipo del petimetre estaba muy presente en el imaginario colectivo de la época, tal como se puede ver en los sainetes de Ramón de la Cruz, por ejemplo, en $E l$ sarao o, sobre todo, en $E l$ petimetre. Estos personajes están fuertemente caracterizados por su afeminamiento y su obsesión con las apariencias. Martín Gaite, a su vez, los define atendiendo a su propensión por las modas extranjeras: por un lado, menciona que son «seres afeminados y fatuos", pero que también eran «jóvenes de familias ricas, aun cuando no necesariamente aristócratas, que, antes de venir a deslumbrar a sus paisanos e implantar en la corte el último grito de la moda masculina, se habían dado una vueltecita por diversos países, a "correr cortes" -como se decía en la época-, de las cuales traían, más o menos prendida con alfileres, una flamante jerga de galicismos que se apresuraban a implantar» (MARTín GAITE, Carmen. Usos amorosos del dieciocho en España. 1. a edición [1. a edición en castellano: 1973]. Madrid: Siruela, 2017, pp. 68-69). El protagonista de El impío por vanidad es en cierto modo también un petimetre afeminado y afrancesado, pero el narrador no pone demasiado énfasis en esto tanto como en su carácter blasfemo, como más adelante veremos.

19. Se trata de una continuación del Quijote que narra lo que le aconteció a Sancho Panza tras la muerte de su amo. La sátira contra lo francés está presente, sobre todo, en un pasaje en el que un instructor llamado don Aniceto intenta educar a Sancho para que tenga unos modales bastante refinados y amanerados (Delgado, Jacinto María. Adiciones a la historia del ingenioso bidalgo Don Quijote de la Mancha, en que se prosiguen los sucesos ocurridos a su escudero el famoso Sancho Panza. 1. ${ }^{\mathrm{a}}$ reimpresión mexicana [1. ${ }^{\mathrm{a}}$ edición original: 1786]. México: Imprenta del ciudadano Santiago Ferez, 1842, pp. 21-37); en esa escena el autor manifiesta un claro rechazo hacia lo francés, elaborando así un cuadro costumbrista bastante francófobo.

20. Álvarez BARRIENTOS, Joaquín. "Imagen francesa y civilización en la novela del siglo XVIII". En AYMES, Jean-René (coord.). La imagen de Francia en España durante la segunda mitad del siglo XVIII: coloquio organizado por CRODEC. 1. ${ }^{a}$ edición. Alicante: Instituto de Cultura Juan Gil Albert, 1996, pp. $167-176$. 
Don Paco, aunque al principio solo movía a risa al lector, es el único causante de que el final de la obra esté repleto de pasajes especialmente truculentos. Cuando se descubre la verdad sobre él, ya es demasiado tarde para que ningún personaje pueda impedir la tragedia; caso idéntico al de Lovelace en la Clarisa. No obstante, aunque se presente de una manera parecida, el protagonista de esta obra está caracterizado de forma ligeramente distinta a la de los antagonistas de la narrativa de Richardson. Su psicología recuerda más bien a la de uno de los protagonistas de El hombre feliz de Teodoro de Almeida: el conde de Moravia, un sujeto irreligioso cuya falta de fe implica el descontrol de sus pasiones y una angustia existencial a lo Werther, que acaba desembocando en el suicidio. La función de ese personaje en la novela del autor portugués es, sobre todo, moralizante: permite aleccionar sobre lo mucho que sufren aquellos que se alejan de Dios. Por el contrario, en El hombre feliz se nos presenta también el caso opuesto, encarnado en el caballero Uladislao, el otro protagonista de la obra, un honorable caballero cristiano que, por mantener en todo momento su fe en Dios, tiene siempre un carácter alegre; él es el "hombre feliz» que da título a la obra.

En El impío por vanidad podemos ver una dicotomía idéntica en tanto que se opone el cristiano feliz al blasfemo que carece de cualquier tipo de consuelo. El personaje de Eugenio, que representa los valores cristianos, es presentado de un modo bastante favorable y atractivo al comienzo de la novela, precisamente para revestirlo de cierta autoridad y para que pueda ser más efectivo como instrumento moralizante. El autor lo caracteriza, en pocas palabras, como un joven "de un ingenio perspicaz y brillante, de un entendimiento claro y despejado, de una memoria enriquecida de todo lo más particular que ofrece la historia de su nación, de un espíritu ameno, de un alma sensible, y de un corazón íntimamente penetrado de los augustos sentimientos de la religión» (p. 3, la cursiva es nuestra). Al poco de describir al personaje de Eugenio, el narrador inserta un pasaje en primera persona, relativo a sus viajes por Europa, donde entendemos algo más el funcionamiento de esa "alma sensible»:

La situación más terrible en que me vi en el largo tiempo de mi viaje (le dijo un día) fue cuando enfermé en Londres. Luego que me vi en la precisión de hacer cama, sentí caer sobre mi corazón un monte de tristeza. Agobiado de dolor, no concebía más que ideas melancólicas; mis ojos oprimidos de un terrible peso estaban siempre cerrados; oía las amorosas reflexiones que a veces me hacía Teodoro, pero lejos de consolarme, me eran importunas: tal vez sentía bañado mi rostro con las lágrimas que derramaba para endulzar mis penas, pero todo era inútil: me hallaba incapaz de consuelo. Mi corazón corría siempre en busca de mi adorada madre, mas era en vano: corría inútilmente tras una sombra que jamás podía alcanzar. [...] ¡Qué terrible pena para mí, y qué dolor aun más acerbo para vuestro corazón, oh madre mía, si ausente de vos me hubiera arrebatado la muerte! (pp. 6-9).

Un personaje con semejante sensibilidad, que da señales de haber atravesado una angustia existencial bastante propia del siglo, está llamado a ganarse la 
simpatía de muchos lectores del XVIII para reconducir el carácter del público. La proliferación de la filosofía sensualista, gracias a autores como Condillac, fue algo bastante característico de ese siglo. Rousseau, por ejemplo, le concede especial importancia a la sensibilidad humana en algunas de sus obras ${ }^{21}$. En el caso del ginebrino, su carácter bien puede relacionarse con su heterodoxia con respecto al catolicismo $^{22}$; por el contrario, si Martínez Colomer decide caracterizar a Eugenio como alguien sensible y a la vez católico es precisamente para hacer ver a sus lectores que la ortodoxia católica no es de ningún modo incompatible con las personas altamente sensitivas; es más, si Eugenio llega a acceder a la religión cristiana es precisamente por ser así. Al final de la novela, este personaje da a entender hasta qué punto la angustia existencial previa a la muerte puede arrastrar a un hombre hasta el seno de la religión católica: «En aquel momento fatal todo desaparece, y queda el hombre solo [...], y ve abierto el abismo que ha de tragarle en breve: desvía de allí los ojos espantados, quiere levantarlos hacia el cielo que jamás se ha atrevido a mirar, y ve al soberano juez que con aspecto terrible le presenta el libro de leyes que ha despreciado siempre» (pp. 147-148). Estas palabras las pronuncia Eugenio refiriéndose a la muerte de don Paco; no obstante, si recordamos el pasaje del principio que hemos citado anteriormente, veremos que también el propio Eugenio ha estado a las puertas de la muerte, y es totalmente consciente de hasta

21. Veamos, por ejemplo, el siguiente fragmento del Emilio: «Nacemos sensibles, y desde nuestro nacimiento somos afectados de diversas maneras por los objetos que nos rodean. Tan pronto como poseemos, por así decir, conciencia de nuestras sensaciones, estamos dispuestos a buscar o rechazar los objetos que las producen, en primer lugar sean agradables o desagradables, luego según la conveniencia o inconveniencia que encontramos entre nosotros y esos objetos, y, por último, según los juicios que tengamos sobre la idea de felicidad o de perfección que la razón nos da. Estas disposiciones se extienden y afirman a medida que nos volvemos más sensibles y más esclarecidos; pero, coaccionados por nuestros hábitos, se alteran más o menos con nuestras opiniones. Antes de esa alteración, esas disposiciones son lo que yo llamo en nosotros la naturaleza» (RoussEAU, Jean-Jacques. Emilio o De la

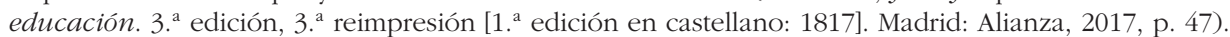
Para Rousseau, las sensaciones recibidas desde la infancia marcan irremediablemente el carácter de cada ser humano. No obstante, el interés por la sensibilidad del ginebrino no se limita a lo estrictamente pedagógico. El protagonista de su novela La nueva Eloísa está caracterizado por ser especialmente susceptible a las emociones frente a los estímulos externos, lo cual da lugar a fragmentos de gran lirismo: "QQué fatal presente del cielo es un alma sensible! Quien lo reciba, que se espere de no tener sino dolor y desdichas en la tierra: Vil juguete del céfiro y las estaciones, del sol o las nieblas, del cielo cargado o despejado, estará triste o contento según dicte el capricho de los vientos» (RousseAu, Jean-Jacques. $L a$ nueva Eloísa. 1. ${ }^{a}$ edición [1. ${ }^{a}$ edición en castellano: 1814]. Madrid: Cátedra, 2013, p. 227).

22. Al abordar la religión desde una óptica sensualista, ROUSSEAu lleva a cabo afirmaciones tan heterodoxas como la siguiente: «Percibo a Dios por todas partes en sus obras; lo siento en mí, lo veo a mi alrededor, pero tan pronto como quiero contemplarlo en sí mismo, tan pronto como quiero buscar dónde está, qué es, cuál sea su sustancia, se me escapa, y mi espíritu turbado ya no percibe nada” (2017, op. cit., p. 439). Si esta sentencia es contraria al dogma católico no es tanto por la afirmación en sí misma, sino por sus implicaciones; está diciendo que no puede contemplar a Dios porque carece de estímulos sensoriales para ello, lo cual invalidaría sacramentos como la eucaristía al negar una comunión con la divinidad por esa vía. 
qué punto es sublime una experiencia así. Caso idéntico es el de Uladislao en $E l$ hombre feliz. Al principio de la novela, al encontrarse con el conde de Moravia y ver la angustia existencial que está atravesando, le declara lo siguiente:

Creed, dice Miseno ${ }^{23}$, que mi genio ha sido bastantemente fogoso, y las membranas de mi corazón sumamente delicadas; por eso los primeros encuentros de la llamada desgracia me dejaron muy herido y ensangrentado, con un dolor tan vivo, tan intenso e insoportable, que me llegué a ver casi muerto, o por lo menos loco y desesperado. Mas esta divina filosofía me animó de manera, que para mí fue un bálsamo que curó mis heridas antiguas, y me infundió valor para mirar con desprecio las que pudiese recibir de nuevo ${ }^{24}$.

Del padre Almeida probablemente tome la dicotomía de religioso/irreligioso, que también es identificada con la dicotomía de feliz/infeliz ${ }^{25}$; el que cree en Dios, todo lo puede; el que no, vivirá lleno de tormentos. No obstante, Martínez Colomer en este caso extrapola esas dicotomías a su época contemporánea, y se aprovecha de la nueva sensibilidad de su siglo para extremar el horror que intenta inspirar en sus lectores hacia la vida irreligiosa.

La intención principal del autor es atacar el contagio francés; atacar, de entrada, el amaneramiento y las costumbres, pero principalmente la filosofía francesa de la Ilustración; son los libros contrarios al catolicismo los que suponen el motor principal de la acción. El costumbrismo resulta bastante eficaz para ridiculizar todo lo relativo al comportamiento y la vestimenta de los afrancesados; no obstante, acaba resultando insuficiente para atacar su filosofía, y por ese motivo el autor necesita apelar a la sensibilidad de los lectores para mostrar que la filosofía más radical de la Ilustración no conduce de ningún modo a la felicidad, sino al más terrible de los sufrimientos.

\section{EL ATAQUE CONTRA LA FILOSOFÍA ILUSTRADA HETERODOXA}

Al atribuir la perversidad y la infelicidad a una persona imbuida de una cosmovisión exageradamente heterodoxa, el autor acaba achacando eso mismo a todos los pensadores que se hayan desviado lo más mínimo del catolicismo; la crítica a estos últimos es, de hecho, lo más importante de la novela. Al fin y al cabo, don Paco es un personaje de ficción, pero en la realidad contemporánea del autor existían afrancesados de ese estilo y, sobre todo, existían los filósofos a los que hace alusión mientras discute con Eugenio, cuyas obras eran cada vez

23. "Miseno» es el nombre que adopta Uladislao al concluir su vida heroica y pasar a una vida de ermitaño, retirado del mundo y entregado a la virtud cristiana.

24. Almeida. Op. cit., p. 28.

25. Menéndez Pelayo también encuentra relación entre la obra de Martínez Colomer y la del padre Almeida (MEnÉndez Pelayo, Marcelino. Historia de los heterodoxos españoles [2 vols.]. 2. ${ }^{a}$ edición [1. ${ }^{a}$ edición original: 1880-1882]. Madrid: La Editorial Católica, 1956, v. 2, p. 619). 
más difundidas y aclamadas por los españoles afrancesados. Será necesario, por ello, que examinemos a qué filósofos en concreto critica Martínez Colomer en su obra; vemos, así, ataques a Helvétius (p. 26), a Voltaire (p. 73), a Bayle (p. 74) y, principalmente, a Rousseau (p. 65).

Es muy destacable que sea precisamente Helvétius el primer filósofo que se menciona. Si bien la mayoría de los ilustrados sostenían que las pasiones fuertes y exaltadas se debían moderar y evitar, por ser fuente de desequilibrios irracionales, Helvétius consideraba que "A las pasiones fuertes debemos los descubrimientos y maravillas de las artes: estas deben ser consideradas como la semilla productora del espíritu y el resorte poderoso que lleva a los hombres a las grandes acciones ${ }^{26}$. Es lógico, por ello, que don Paco sea un sujeto apasionado hasta la transgresión teniendo en cuenta los autores en los que basa su comportamiento. La idea helvetiana que pronuncia al comienzo de la novela es que «No hay más virtud que lo que a cada uno le importa obrar» (p. 35); y, efectivamente, Helvétius sostiene que «el interés personal es en cada sociedad el único canon del mérito de las cosas y las personas ${ }^{27}$. El racionalismo ilustrado, de nuevo, conduce a la relatividad moral en tanto que pone en duda la legitimidad de los mandamientos divinos; eso conducirá a don Paco a un dolor metafísico al perder el consuelo que un posible Dios pudiese darle a cambio de la obediencia a los dogmas.

Mientras que la filosofía de Helvétius tiene apreciable relación con el conjunto de la obra, no se puede decir lo mismo de Voltaire, porque de él en ningún momento se critica una sola idea concreta. Su nombre, de hecho, únicamente se menciona en dos ocasiones: la primera vez que aparece (p. 70) es en una enumeración, junto a Helvétius y Rousseau; todos estos filósofos son acusados de "ofuscar el espíritu» de don Paco, pero no se especifica en ningún momento de qué modo lo ha ofuscado Voltaire en particular. La única alusión a una de sus obras (p. 73) viene dada por Eugenio, quien pretende hacer ver al marqués que incluso entre los filósofos franceses a los que admira hay argumentos para defender la religión católica, y cita una frase suya: "Ley (de los cristianos) que al mundo todo une y concilia en recíproco amor (dice Voltaire), solo es dictada por eterna y celestial sabiduría». Esta sentencia está extraída de la tragedia $\mathrm{Zaire}^{28}$, en la traducción de Vicente García de la Huerta ${ }^{29}$; no obstante, está completamente sacada de contexto. No la pronuncia ningún personaje que se haga portavoz de las ideas del propio Voltaire, sino que la formula una cristiana cuya vida acaba siendo arruinada por la religión, lo que contribuiría a reforzar la idea de que las religiones son perniciosas

26. Helvétius (Claude-Adrien Schweitzer). Del espíritu. 2. ${ }^{a}$ edición [1. ${ }^{a}$ edición en castellano: 1984]. Pamplona: Laetoli, 2016, p. 177.

27. Helvétius. Op. cit., p. 61.

28. [VOLTAIRE (François-Marie Arouet)]. La fe triunfante del amor y cetro, o Xayra. 1. a edición. Segovia: Imprenta de don Antonio Espinosa, 1790, p. 9.

29. Dicha traducción se publicó en nuestro país pocos años antes de El impío por vanidad. Es muy probable que esta sea la versión que Martínez Colomer haya utilizado para citar a Voltaire. 
para los seres humanos ${ }^{30}$. Además, García de la Huerta reelaboró la tragedia sin respetar demasiado el texto original, e intentó poner especial énfasis en defender el catolicismo; por ello, ni siquiera es del todo lícito decir que Martínez Colomer realmente esté citando a Voltaire. Está totalmente fuera de lugar que intente tachar a Voltaire de impío o irracional por blasfemar contra la religión católica y luego "defenderla»; Martínez Colomer no demuestra el más mínimo conocimiento de esas «blasfemias», y la supuesta "defensa» de la religión católica de la que acusa a Voltaire ni siquiera es tal. Todo parece indicar que el autor de El impio por vanidad se ha limitado a dejarse llevar por los prejuicios contra Voltaire que durante muchos años hubo en nuestro país, y con esos mismos prejuicios ha efectuado una crítica sin mucho fundamento ${ }^{31}$.

Respecto a Bayle, es criticado por afirmar, supuestamente, que «los verdaderos cristianos no es posible que lleguen a formar un Estado permanente» (p. 75); dicha crítica viene precedida de una larga cita de Montesquieu, quien anteriormente también lo había atacado. El caso de Bayle es idéntico al de Voltaire: viene citado por medio de terceros, y sus razonamientos aparecen distorsionados y sacados de contexto. Remitámonos, si no, a las palabras del propio Bayle: «No creo que pueda llegar una desgracia mayor que si gobernarais vosotros o reinaran los sacerdotes ${ }^{32}$. No es lo mismo formar un Estado que gobernarlo; la crítica de Bayle incide sobre lo segundo, pero fingir que está acusando a los católicos de una incapacidad total para vivir en sociedad añade una contundencia mucho mayor a la crítica, aunque no se apoye esta precisamente en argumentos racionales. Teniendo en cuenta este caso, y el ya citado de Voltaire, podemos deducir la verdadera postura de Martínez Colomer con respecto a estos dos filósofos: no pasa de la crítica superficial, apelando constantemente a los prejuicios y a la escasa formación de sus posibles lectores. Por este motivo, aunque en el texto haya una marcada voluntad de parecer racional, una novela semejante no es sino producto de una acusada actitud dogmática y hasta cierto punto antiilustrada por parte de su autor, quien cierra los ojos a todas las posibles sospechas que el pensamiento racional hubiese podido poner sobre el catolicismo. Que ni siquiera conozca realmente la obra de dos de los filósofos a los que está criticando quizá sea producto, por un

30. En la obra original, la frase la pronuncia Zaire, la protagonista, personaje que vive en contradicción perpetua entre dos impulsos: el amor y la religión. Ella, a pesar de ser cristiana, está enamorada de un musulmán llamado Orosmán. Las diferencias religiosas entre ambos suponen un obstáculo insalvable para su amor, que acaba desembocando en un final trágico. La religión, en definitiva, es vista como algo que entorpece las relaciones humanas y que trae más problemas de los que soluciona.

31. Caso totalmente contrario será el de Pablo de Olavide en El Evangelio en triunfo. El peruano había tenido oportunidad de conocer a Voltaire en persona y conocía con detalle sus ideas, por lo que en su novela argumenta con bastante más acierto para atacarlas.

32. BAyle, Pierre. La católica Francia. 1. ${ }^{\mathrm{a}}$ edición en castellano. Madrid: Ediciones del Laberinto, 2000, p. 96. Con el vocablo "vosotros» Bayle hace referencia a los católicos, a quienes critica al tiempo que se posiciona en defensa de los protestantes. 
lado, de las dificultades que tuvieron la circulación de muchas de estas obras en España ${ }^{33}$; del miedo propio de aquellos que, aferrados a la idea de la salvación cristiana, ven toda su realidad desmoronada en el caso de perder su fe. Más adelante veremos, de hecho, que el espanto provocado por la idea de la muerte sin una salvación detrás es el tema principal de la obra.

No obstante, en el caso de Rousseau, al igual que en el de Helvétius, el conocimiento que Martínez Colomer muestra es bastante mayor; también es mayor su relevancia en la novela. Hay un instante en el que, de hecho, don Paco destaca de Rousseau el ser "muy enérgico» y "muy sublime» (p. 92); un así será el de don Paco, frenético hasta el punto de mantener sus principios impíos incluso en el momento de su muerte. Para entender su importancia, será necesario ver en detalle qué ideas suyas tienen presencia en la narración. La primera de ellas es afirmada por el marqués con mucho ímpetu:

Patrañas, dijo entonces, cerrando el libro y arrojándolo sobre el bufete: de esta suerte preocupan a la juventud, la entorpecen y la dejan sin libertad para pensar. [...] Porque ¿quién sino la tiranía ha cargado sobre la mísera humanidad el pesadísimo yugo de tantos preceptos y de tantas leyes, y la ha seducido con los trampantojos del infierno, de la gloria, de...? [...], «pues no es asunto de poca monta solo el saber si hay Dios» (pp. 59-61).

Sabemos que estas ideas provienen de Rousseau porque así lo afirma Eugenio justo después de que don Paco emita su discurso (p. 63). Y, en efecto, ideas muy similares pueden ser encontradas en, por ejemplo, el Emilio, sobre todo en lo relativo a la formación religiosa de la gente de muy poca edad, si bien el ginebrino las desarrolla con muchísima más coherencia:

Locke quiere que se empiece por el estudio de los espíritus, y que se pase luego al de los cuerpos; ese método es el de la superstición, de los prejuicios, del error; no es el de la razón, ni siquiera el de la naturaleza bien ordenada; es taparse los ojos para aprender a ver. [...] Esa palabra espíritu no tiene ningún sentido para quien no ha filosofado. [...] Todo niño que cree en Dios es, pues, necesariamente idólatra, o al menos antropomorfita; y cuando la imaginación ha visto una vez a Dios, es muy raro que el entendimiento lo conciba. Ése es precisamente el error a que conduce el orden de Locke ${ }^{34}$.

Rousseau afirma que comprender la existencia de Dios es un asunto muy complicado, que escapa por completo a las capacidades de un niño; el marqués de Viruenga viene a repetir más o menos lo mismo en la novela de Martínez Colomer, pero simplificándolo todo a conveniencia; pone especial hincapié en lo muy absurdo que resulta llenar la mente de la gente joven con cuestiones relativas a la religión. No obstante, Martínez Colomer acusa de «blasfemia» una consideración

33. En la bibliografía se indican las fechas en las que se tradujeron por primera vez al castellano.

34. Rousseau. Op. cit., 2017, pp. 403-405. 
semejante: "Un sordo susurro corrió por los circunstantes luego que el marqués acabó de proferir esta blasfemia. Faustina se cubre la cabeza con las manos, Carmela se sorprende, Casilda asombrada huye con precipitación, y todos se miran unos a otros como enajenados» (pp. 61-62). Los personajes de la novela acaban de escuchar a un afrancesado que pronuncia ideas ilustradas; no obstante, por su reacción parece que han visto a alguna clase de monstruo horrible que les ha causado el mayor de los espantos. El estilo que Martínez Colomer emplea en ese fragmento, sincopado y tremendo en la elección de sustantivos, recuerda a la estética burkeana ${ }^{35}$, en boga en aquellos años, y contribuye a inferirle cierto carácter espantoso a un pasaje que, en principio, no debería tener nada de terrorífico.

Adviértase que, de esta forma, la filosofía de Rousseau pasa a ser completamente demonizada. El ginebrino, en su Emilio, tan solo se había limitado a señalar la complejidad y lo complicado de un asunto como lo es la existencia de Dios; ni siquiera niega la existencia de la divinidad. No obstante, Martínez Colomer parte del supuesto de que cualquier persona sensata y bondadosa va a acatar la existencia de Dios sin cuestionársela; por ello, considera que la actitud de quien señale siquiera lo complejo del asunto no es más que «un aborto de un corazón depravado, que se esfuerza en vano para vivir tranquilo en medio de sus desórdenes, fingiéndose que no hay Dios: pero ¿cómo puede durar mucho tiempo esta torpe ilusión, cuando esa prodigiosa multitud de objetos que le rodean no cesan de gritarle que hay un Dios...?» (p. 63) ${ }^{36}$.

35. Para Burke, el terror, por ser causa del principio de autoconservación, pasa a ser considerado la principal fuente de lo sublime, esto es, las más intensas emociones que el ser humano puede experimentar (Burke, Edmund. De lo sublime y lo bello. 2. ${ }^{a}$ edición [1. ${ }^{a}$ edición en castellano: 1807]. Madrid: Alianza, 2014).

36. De hecho, en un intento de desacreditar por completo la figura de Rousseau, Martínez Colomer emprende algo parecido a lo que hizo con Voltaire: deslegitimar la argumentación de un filósofo anticlerical mediante comentarios de ese mismo filósofo tergiversados y sacados de contexto. Hay una ocasión en la que Teodoro le intenta demostrar a don Paco que incluso Rousseau admiraba la religión católica: "Esta luz superior, la revelación; esto es, la Escritura Santa, cuya majestad admira y asombra a vuestro apóstol Rousseau" (p. 67). Y esto es cierto, ya que en el propio Emilio se pueden encontrar fragmentos como el siguiente: "También os confieso que la majestad de las Escrituras me sorprende, que la santidad del Evangelio habla a mi corazón. Ved los libros de los filósofos con toda su pompa: iqué pequeños son al lado de ése!» (Rousseau. Op. cit., 2017, p. 488). De igual manera, en la novela de Martínez Colomer también se utiliza a Rousseau para atacar a los propios filósofos de la Ilustración (pp. 75-77), citando de memoria un pasaje del Emilio en el que los acusa de no ser muy fiables (RoussEau. Op. cit., pp. 495-496). Desde luego, el ginebrino muestra una actitud claramente ecléctica, algo propio del racionalismo ilustrado por sopesar los pros y los contras de algo antes de adoptar una postura totalmente radical al respecto. Sin embargo, ese eclecticismo es visto por Martínez Colomer como algo ridículo, y lo utiliza para intentar desacreditar a Rousseau: «Ya prueba el ateísmo, ya lo confuta con los argumentos más irresistibles: ¿qué crédito merece pues un hombre opuesto siempre a sí mismo?» (p. 66); "Su autoridad en este punto es de tanto peso como el mosquito de Lokman sobre los cuernos del toro" (p. 77). 
Es evidente que la actitud de Martínez Colomer es completamente exagerada y sensacionalista. Es amplio el subjetivismo que hay aquí; el autor no ataca al ginebrino utilizando argumentos racionales, sino mostrando escándalo y horror, llegando incluso a lo burkeano. Hay, por encima de todo, irracionalismo, ya que la argumentación racional es combatida con cláusulas contundentes teñidas de un ímpetu violento, como lo de «semejante blasfemia [...] no es más que un aborto de un corazón depravado». La frialdad analítica de la Ilustración es atacada y demonizada; en su lugar, el autor propone sacralizar la ingenuidad de aquel que, sin tener mucha idea de filosofía o teología, asume que Dios existe con tan solo observar la realidad, porque «esa prodigiosa multitud de objetos que le rodean no cesan de gritarle que hay un Dios».

Con la siguiente idea roussoniana que aparece enunciada en la novela ocurre algo más o menos similar: el marqués afirma que "la religión cristiana es contraria a la buena constitución de un Estado» (p. 70), y justo después Eugenio logra advertir que se trata de una idea de Rousseau. En efecto, una sentencia casi idéntica aparece en Del contrato sociaß ${ }^{37}$ : "La ley cristiana es en el fondo más perjudicial que útil para la constitución fuerte del Estado" ${ }^{38}$. No obstante, adviértase una diferencia muy sutil: Rousseau no está diciendo que lo incompatible con el Estado sea la religión cristiana, sino la ley cristiana. En su obra no hay tanto un ataque al cristianismo como tal, sino a sus leyes; le parecen incompatibles con el orden público porque suponen una división de poderes entre los sacerdotes y los soberanos. Martínez Colomer, por tanto, está tergiversando la filosofía de Rousseau; no podemos decir tanto que haya un ataque contra el ginebrino, sino contra una filosofía imaginaria, exagerada y desfigurada que es puesta en boca del autor del Contrato social. No obstante, el plasmar las ideas del autor del Emilio como algo más blasfemo de lo que realmente es permite al autor de nuestra novela insistir con mayor intensidad en la validez del tradicionalismo católico: «Si así como Rousseau ha reproducido esta impostura infame, hubiera visto el modo con que la desvanece Tertuliano en su apología, tal vez hubiera quedado convencido" (p. 71).

Al hablar de «impostura infame», Martínez Colomer identifica las ideas de Rousseau con «aquella calumnia que en los primeros siglos de la Iglesia se formó contra los cristianos, llamándolos inútiles para el comercio y para la vida civil» (pp. 70-71). No tiene mucho sentido equiparar la filosofía del XVIII a la de los primeros siglos del

37. La idea aparece enunciada en Del contrato social; no obstante, Martínez Colomer afirma que tal proposición forma parte del Emilio (p. 71). Aunque en el Emilio hay un espíritu crítico hacia el cristianismo, en ningún momento se habla de forma tan explícita sobre la directa incompatibilidad de la religión cristiana con la constitución de un buen Estado. El autor de El impio parece haberse confundido entre las dos obras de Rousseau.

38. Rousseau, Jean-Jacques. Del contrato social. Sobre las ciencias y las artes. Sobre el origen y los fundamentos de la desigualdad entre los hombres. 1. ${ }^{a}$ edición, 7. ${ }^{a}$ reimpresión [Primeras ediciones en castellano: 1799 (Del contrato social), 1909 (Discurso sobre las ciencias y las artes), 1820 (Sobre el origen y los fundamentos de la desigualdad entre los bombres)]. Madrid: Alianza, 1990, p. 135. 
cristianismo; aunque se puedan encontrar similitudes, la postura del ginebrino es mucho más madura y compleja que la de esos primeros calumniadores del cristianismo ${ }^{39}$. Resulta absurdo remitirse a un autor de finales del siglo II y principios del III para defender el cristianismo en el siglo XVIII, sobre todo cuando ni siquiera ha sido atacado de la forma en que se pretende hacer creer al lector. Sin embargo, al autor le resulta increíblemente conveniente hacer ver que Rousseau es tan «infame» como los perseguidores del cristianismo en sus orígenes; mediante esa falacia, la filosofía irracional y cristiana que aquí se ofrece cobra mucha más fuerza.

El triunfo del catolicismo más conservador conllevará, necesariamente, una demonización no solo de la irreligiosidad, sino de cualquier otro culto religioso que suponga la más mínima desviación de los dogmas de la Iglesia. Rousseau, de hecho, ni siquiera era ateo, sino que profesaba el teísmo o la religión natural, que se diferencia del deísmo por admitir no solo la existencia de Dios, sino también la revelación (Rousseau, 2017: 467); no obstante, no hay de ningún modo una aceptación total de los dogmas de la religión católica. Dentro del Emilio viene inserta la Profesión de fe del vicario Saboyano, un tratado teológico en el que el ginebrino justifica sus inclinaciones religiosas. Martínez Colomer, sin embargo, deja muy clara por boca de Eugenio su opinión sobre la Profesión de fe y sobre el teísmo en general:

Rousseau, en los cortos intervalos que las pasiones daban lugar a que su razón brillase plácida y tranquila, conocía la existencia de un Dios infinito y perfecto en todos sus atributos, pero nunca le honró como debía, ni levantó jamás su orgullosa frente para manifestarle el más ligero reconocimiento: a cuya causa, endureciéndose de cada día más su corazón, resistía rebelde a toda inspiración. Llegaba a conocer la santidad del Evangelio de Jesucristo, la sencillez, la elevación, la moral sublime de sus Escrituras; pero apenas reflexionaba que las puras y sublimes máximas de aquel libro divino le prohibían absolutamente el desahogo y la satisfacción de sus pasiones, cuando todas ellas se rebullían, por decirlo así; y recobrando su imperio, se apiñaba alrededor de la razón, la asaltaban furiosas, la abatían, no la permitían hablar, y solo se dejaba oír su tono imperioso y feroz. ¡Qué podía hacer entonces un hombre enteramente abandonado al tiránico despotismo de sus pasiones! Tenazmente soberbio por la vastedad de sus talentos, y fiado solo de la extensión de sus luces, emprendía nuevos rumbos, y se proponía investigar lo que solo debía creer. De esta vana y siempre peligrosa curiosidad, nacieron sus descarríos, de ahí el encontrarse cercado de tinieblas a los primeros pasos, de ahí el proseguir caminando a

39. "Ahora que ya no hay y que no puede haber más religión nacional exclusiva, deben tolerarse todas aquellas que toleran a las demás, siempre que sus dogmas no tengan nada contrario a los deberes del ciudadano. Pero quien se atreva a decir: fuera de la Iglesia no hay salvación, debe ser echado del Estado» (Rousseau. Op. cit., 1990, pp. 140-141). Pese a lo que diga Martínez Colomer, Rousseau está predicando precisamente tolerancia hacia los cristianos y hacia cualquier tipo de culto; únicamente condena el fanatismo. Su actitud no tiene realmente mucho que ver con la intolerancia habida hacia los primeros cristianos. 
ciegas, y de ahí finalmente el precipitarse en un abismo de errores (pp. 98-100, la cursiva es nuestra).

Según el autor de lo que acabamos de citar, Rousseau comenzó siendo un hombre ilustrado, racional, y ese racionalismo suyo fue lo que le llevó a «investigar lo que solo debía creer». Utilizar la razón le imbuye en la soberbia necesaria como para cuestionar los dogmas del catolicismo; la consecuencia de esto es, precisamente, que, al no considerar esas leyes dignas de ser seguidas, no encuentra motivos lógicos por los que no dar rienda suelta a la exaltación de las pasiones. Por paradójico que resulte, el racionalismo más frío ha desembocado en el apasionamiento más febril.

De todas las consideraciones sobre Rousseau que Martínez Colomer lleva a cabo en su novela, tal vez esta sea la menos inexacta. Bien es cierto que, en todo momento, el Rousseau de la novela es una versión desfigurada del mismo, más estúpida y más fácil de ridiculizar; no obstante, las palabras del último fragmento son más o menos ciertas. Quizá haga juicios demasiado rotundos para una persona que no hubiese conocido de primera mano a Rousseau; sin embargo, alguien que conozca la obra del ginebrino sabrá que Martínez Colomer lleva parte de razón. El autor del Emilio y del Contrato social es también autor de La nueva Eloísa, novela que, según Vázquez, es la primera manifestación del Romanticismo ${ }^{40}$; a su vez, Rousseau también es autor de las Ensoñaciones del paseante solitario, texto de un sentimentalismo similar al de los románticos ${ }^{41}$. Tanto lo racional como lo apasionado tienen cabida dentro de la obra del ginebrino, y no es ninguna imprudencia afirmar que lo segundo es consecuencia de lo primero. Su inclinación hacia lo empírico y lo sensorial le impiden llegar a la paz mental propia de los católicos que mantienen su fe por encima de todo, y esto ni siquiera lo logra suplir con sus creencias teístas: "Oh sabiduría, ¿dónde están tus leyes? Oh Providencia, ¿así es como riges el mundo? Ser bienhechor, ¿qué se ha hecho de tu poder? Veo el mal sobre la tierra" ${ }^{42}$.

Los momentos de la narración en los que aparecen consideraciones sobre la vida y los textos de Rousseau no deben ser tenidos como algo anecdótico; por el contrario, constituyen un pilar fundamental de El impío. Es más: quizá sea totalmente lícito afirmar que Rousseau es, incluso, un personaje de la novela ${ }^{43}$, y no menos importante que los demás. Frente a Voltaire y los otros filósofos que son mencionados, al ginebrino se le dedica mucha mayor atención; así, los juicios sobre él son bastante más extensos y numerosos. Además, su sola presencia

40. VÁZQuEz. op. cit., p. 96.

41. ARmiño, Mauro. "Introducción». En Rousseau, Jean-Jacques. Las ensoñaciones del paseante solitario. 3. ${ }^{a}$ edición. Madrid: Alianza, 2016, p. 17.

42. Rousseau. Op. cit., 2017, p. 441.

43. Nos referimos, no obstante, no al Rousseau real, sino a la versión desfigurada del mismo que Martínez Colomer nos ofrece. 
permite dar lugar a cierto paralelismo: el Rousseau desfigurado de Martínez Colomer es a don Paco lo que Teodoro es a Eugenio. Si Eugenio ha aprendido toda su doctrina católica de manos de su preceptor Teodoro, el marqués se ha imbuido de máximas contrarias al cristianismo a partir de su conocimiento de Rousseau. Vemos, así, un paralelismo entre dos grupos de personajes en confrontación: los cristianos y los irreligiosos. Los dos grupos están formados por un maestro y un aprendiz; los dos grupos participan en el debate filosófico que más páginas de la novela ocupa, y si Rousseau aparece como tal, su nombre es constantemente mencionado, y a él acude el marqués siempre que lo necesita.

\section{LAS ÚLTIMAS CONSECUENCIAS DEL SENSACIONALISMO ANTIILUSTRADO}

Martínez Colomer no se limita a insertar sermones morales, sino que se sirve de una técnica que ameniza bastante la narración, esto es, la confrontación o la disputa filosófica. En El Valdemaro, el personaje de Andrónico emitía largos discursos que eran asimilados sin rechistar por el protagonista de la obra, algo parecido a lo que pueda hacer Montengón en el Eusebio; son estas escenas en las que hay, sobre todo, pedagogía y didactismo ${ }^{44}$. Aquí, sin embargo, la mayoría de los exordios morales vienen insertos en la larga discusión que mantiene Eugenio contra don Paco a lo largo de casi cincuenta páginas (pp. 58-102); los argumentos moralizantes no son empleados como forma de adoctrinar al otro, sino más bien como ataque a la filosofía opuesta que tanto les repugna. Durante ese extenso debate, a pesar de la cantidad de contenido filosófico que introduce, el autor se sirve de un estilo ameno que permite al lector palpar la tensión habida en el ambiente. Veámoslo:

Sellad el labio (prorrumpió entonces Eugenio con ardor); temed siquiera escandalizar a estas señoras que os escuchan, ya que no teméis la ira de Dios que irritáis con vuestras blasfemias [...]: pero decidme, amigo, ¿la casualidad es alguna entidad real, o es nada? Si es nada, ¿cómo la nada puede producir algún efecto? Si es alguna entidad real, ¿̇me haréis el gusto de decirme dónde existe? Y en fin, si existe y es capaz de obrar, permitid que os arranquen el pelo, que será sin duda uno de vuestros ídolos más favoritos, dejémoslo embrollado en cualquier rincón, y vos podréis andaros calvo por ese mundo, hasta que la casualidad os forme una peluca para cubriros. ¡Qué insulto (prorrumpió el marqués todo atufado)! Ese no es momento de disputar con un caballero de mi rango; yo, cuanto he dicho, lo confirmaré con el testimonio de los ingenios más ilustrados. [...] Sin embargo, si no habéis de admitirme, ni autoridades de Santa Escritura, ni doctrina de la Iglesia, ni tradiciones, ni concilios, ni autoridades de Santos Padres, voy a confundiros con las razones y testimonios de vuestros mismos filósofos, y los más decantados. ¡Ah! (exclamó el

44. Menéndez Pelayo también vincula a Martínez Colomer con Montengón (MENÉNDEz PELAYO. Op. cit., v. 2, p. 619). 
marqués): ¿̨con las razones de mis filósofos? ¿Lo admiráis (preguntó Eugenio)? Esa admiración, amigo, me hace pensar que ni aun no los habéis leído. De manera (respondió el marqués rascándose la cabeza) que... si vos... yo... de suerte que... tal... como... No os canséis (acudió Eugenio, viendo la ignorante angustia en que se hallaba el pobre marqués): hacedme el favor de oírme, y veréis si puedo combatiros con las razones de vuestros filósofos [...]. ¡Filósofo miserable! ¡A qué precipicios no te expone el mal uso de la razón! ¡Cómo es que tan vilmente has abusado de este preciso don, y te vales de él como de armas para hacer la guerra, y usurpar los derechos al mismo Dios que tan liberalmente te lo ha concedido! [...] Pero ¿a dónde voy? ¿Por qué me fatigo en reflexiones que tal vez os parecerán inútiles por ser mías? (pp. 61-91).

Obsérvese que en lo que hemos citado no solo hay sermón moral, sino también disputa acalorada; don Paco y Eugenio se enfadan, se gritan e incluso se insultan, mostrando evidente ira el uno hacia el otro con comentarios sarcásticos y colmándose mutuamente la paciencia. Las exclamaciones, los puntos suspensivos y las interrogaciones retóricas dotan al texto de cierta vivacidad no demasiado frecuente en los sermones ilustrados, y le infieren una impresión bastante más realista; es más, el hecho de que no dejen terminar las frases a su interlocutor y que se estén pisando continuamente parece responder a lo que vendría a ser una conversación real. Hay un momento incluso en el que Eugenio se refiere al «mal uso de la razón» como "armas para hacer la guerra»; hay una identificación, así, de las disputas de los filósofos ilustrados con la "guerra", lo cual nos permite relacionar la discusión que están teniendo con alguna especie de contienda.

Uno de los principales aciertos de El impío por vanidad, de hecho, es el de establecer la acción en la España contemporánea al autor, y así permitir el tratamiento de conflictos relativos al propio XVIII español con la sensibilidad necesaria; ya no estamos, como en El Valdemaro, en una Edad Media idílica en la que tienen lugar todo tipo de aventuras y combates entre caballeros, sino en la Edad Contemporánea, donde los nuevos combates son llevados a cabo por filósofos en debates y discusiones acaloradas

En El impío por vanidad don Paco le declara la guerra al cristianismo e incluso a la propia divinidad ${ }^{45}$. Será a la hora de morir cuando reciba el mayor castigo por su irreligiosidad; nos referimos a la angustia experimentada por el que no es creyente en los momentos previos al instante final, momentos en los que no hay consuelo de ningún tipo al no tener garantía de lo que pueda haber o dejar de haber después. Veámoslo en una de las escenas finales:

Cerrados los ojos, entumecido y amoratado el rostro, ya se revolcaba furiosamente agitado de los más extraordinarios estremecimientos, ya se quedaba inmoble

45. No se puede decir que esa "guerra a la divinidad" sea algo consciente; es una "guerra" que viene a ser considerada como tal por Eugenio, quien considera que la actitud de don Paco tiene unas implicaciones así de extremas. 
repitiendo profundos y cansados suspiros. [...] Se agita de nuevo, se estremece; y abandonándose a todo el ímpetu de su rabia, arroja de sí la ropa que lo cubre, rasga las vendas de sus heridas, y parece querer destruirse a sí mismo aquel instante, si fuera posible. ¡Qué espectáculo tan horrendo! Sus ansiosas miradas, sus conmociones involuntarias, sus reiterados estremecimientos, su constante inquietud expresaban del modo más enérgico los crueles remordimientos, y las secretas ansias que le devoraban. En vano el sacerdote que le asiste procura valerse de todos los medios que le inspira su celo activo para convertirle [...]: esta cruel y atroz alternativa solo sirve de enfurecerle más: igualmente le irrita lo dulce y suave, que lo terrible y espantoso. Preséntale finalmente un crucifijo, persuadiéndole del modo más patético, que todavía puede hallar asilo en su clemencia: el infeliz moribundo entonces extiende precipitadamente sus débiles brazos para rechazar aquella sagrada imagen, como si fuera el único objeto de su aversión, lanza una feroz mirada; y como si viera ya al juez terrible que iba a pronunciar en aquel instante su condenación eterna, arroja un grito despechado y lúgubre, vuelve la cabeza a la parte contraria, y muere. ¡Qué muerte! El terror se difunde en breve por todo aquel distrito, la priesa de echar de allí aquel espectáculo de horror, les hace precipitar las diligencias; todos quieren que se arroje luego, pero nadie se atreve a llegar hasta él: tal era el pavor que inspiraba aquel monstruoso y fétido cadáver (pp. 141-145, la cursiva es nuestra).

La angustia, el desasosiego y el tormento vital pueden ser palpados en esas «secretas ansias» que lo devoran. Alejado de la religión, de la Iglesia y de sus dogmas tranquilizadores, don Paco no tiene absolutamente nada a lo que aferrarse en las últimas horas de su vida. Se ve precipitado, así, a una angustia extrema, consecuencia de haber asumido la aniquilación definitiva del ser. Para su mente blasfema, no cabe imaginar la resurrección en un mundo supraterrenal; por el contrario, insiste en rechazar el crucifijo y precipitarse a la incertidumbre que hay más allá de la muerte. En un siglo anterior al XVIII, resultaba imposible concebir una angustia semejante en los momentos previos a la defunción; al no estar el racionalismo en una etapa tan avanzada y al no existir los filósofos ilustrados que supusieron la base de la ideología de don Paco, difícil era encontrar en la literatura de los siglos anteriores una escena similar. No obstante, para 1795 la mentalidad ilustrada estaba ya bastante desarrollada, y ese mismo pensamiento ilustrado será el que posibilite la existencia de escenas como la que acabamos de citar.

Para el autor de esta novela, algo como la razón pura, alejada de toda fe, no puede traer otra cosa que el más terrible de los malestares. Así lo declara el propio Eugenio después de asistir a la escena de la muerte del marqués: «¿Cómo no buscaba entonces los recursos de su vana filosofía para consolarse? ¿Cómo no se figuraba entonces a la muerte como un sueño plácido y tranquilo que iba a sustraerle dulcemente de esta vida fugaz, para transportarlo al abismo de la nada? ¡Mas ay, y cuán vanos son entonces todos los recursos de esa falsa filosofía!» (p. 147). De nuevo la mentalidad de la Ilustración más heterodoxa pasa a ser vista como «falsa filosofía» que no ha causado más que daño en los hombres. El irracionalismo del cristiano que mantiene su fe por encima del empirismo y de la razón será visto 
como la única vía mediante la cual el hombre puede alcanzar la felicidad: «Si con un corazón profundamente penetrado de los sentimientos de piedad y de respeto hubiera entrado Rousseau a leer las santas escrituras, contentándose con entender lo que se le permitiera [...], su entendimiento se hubiera sometido con docilidad a la creencia de lo que es infinitamente superior a su capacidad" (pp. 100-101). La razón no solamente es insuficiente para alcanzar la felicidad, sino que debe ser evitada, siendo sustituida por cierta clase de veneración humilde que impide cuestionar racionalmente todo lo relativo a los dogmas católicos.

En El hombre feliz eran demonios y seres sobrenaturales los encargados de atormentar al conde de Moravia y alejarlo de la religión; en El Valdemaro ocurría algo muy parecido con el personaje de Piromanto, un sujeto bastante siniestro y con cierto aire sobrenatural que desempeña una función muy similar. No obstante, en El impío ese papel le está reservado a los filósofos ilustrados, cuya «falsa filosofía” ejerce el papel que ejercían las criaturas malignas de las otras dos novelas. Obsérvese que de esta forma se está demonizando, literalmente, la faceta más heterodoxa de la Ilustración.

Don Paco, al principio de la historia, se nos muestra como una clase de fantoche ridículo. No obstante, el marqués va revelando poco a poco una actitud que, lejos de provocar risa, suscita más bien el escándalo por suponer afrentas hacia la religión católica. Pensemos, por ejemplo, en los comentarios que hace después de contemplar las pinturas alegóricas con relación a la religión: afirma que «en lugar de estos bichos, con mejor gusto hubiera hecho pintar [...] la hermosa Diana enteramente desnuda en el baño como la encontró Acteón» (p. 33). Actitud sensual, lujuriosa y materialista, que supone un desprecio bastante contundente hacia lo católico por preferir el mundo terrenal al espiritual. El carácter terrible de don Paco se intensifica en el momento en el que comienza a discutir acaloradamente con Eugenio; en esa escena, de hecho, llega a mostrar una actitud más bien violenta al hacer gala de un flagrante desprecio hacia el libro de los evangelios: "Patrañas, dijo entonces, cerrando el libro y arrojándolo sobre el bufete: de esta suerte preocupan a la juventud, la entorpecen y la dejan sin libertad para pensar» (pp. 59-60). A estas alturas ya no se busca mover al lector a risa, sino también a espanto con semejantes blasfemias. Y ese espanto habrá de ser llevado al extremo en la última parte de la novela, no solo en la escena de su muerte, sino en todo lo tocante a su relación con Carmela.

Que una persona tenga una vestimenta estrafalaria y unos ademanes muy raros puede resultar muy gracioso; que esa misma persona insulte con facilidad los principios del catolicismo, no tanto; pero en el momento en el que ese sujeto logra manipular a una muchacha inocente hasta el punto de arrastrarla al suicidio, lo cómico ya no solo desaparece, sino que es sustituido por lo más extremadamente trágico. Observemos, si no, la escena en la que Eugenio contempla cómo Carmela se intenta arrancar la vida: 
Al débil resplandor de las estrellas que brillaban en medio de un cielo claro y despejado, contempla la sosegada noche, cuya oscuridad infunde un dulce pavor en su espíritu. [...] El agradable susurro que el manso viento forma entre las hojas de los altos chopos, el suave murmullo de los arroyos que corren atropellados por entre la menuda hierba, [...] todo lo arrebata a su admiración. Embelesado en esa diversión tranquila, observa que por la cumbre de un empinado monte que tenía al frente, se asoma con plácido sosiego la plateada luna, y todo muda de aspecto: una nueva escena se le presenta en aquel magnífico teatro. [...] Escucha atento, y percibe unas voces que decían: No temas Casilda; si me amas, si alguna recompensa quieres dar al afecto que me debes, no temas, hiere, rómpeme el pecho, derrama la infame sangre... ¡Ay de mí! Arranca este vil espíritu que me anima: ¿qué te embaraza? Casilda... dulce hermana mía... ¿Mas tú suspiras? ¿Te estremeces? ¿Qué indica ese temblor que así te agita? Habla... ¿̇no respondes? ¡Ay! Aún eres más cobarde que yo. ¿Querrás que viva para que mi deshonra se publique? Para que cubierta de infamia sirva de negro y eterno oprobio... No, Casilda, no; no, hermana: y pues no quieres ser piadosa conmigo, desde este elevado balcón buscaré mi precipicio donde sepultada quede para siempre... (pp. 124-127).

Obsérvese cómo el autor logra evocarnos, en primer lugar, un paisaje que recuerda al locus amoenus: nos habla del "agradable susurro" del viento, de "plácido sosiego", etc.; frente a algo tan tranquilo, nos antepone una escena de gran truculencia para crear mayor contraste e impacto en el lector: el intento de suicidio, presentado de una manera que resulta espeluznante. Es evidente que ya no queda rastro alguno de comedia; por el contrario, en una escena semejante tiene lugar no ya solo lo trágico, sino incluso lo terrorífico y lo burkeano; y la escena que acabamos de citar no es sino la consecuencia de las acciones infames y atroces del impío. El marqués ha herido los sentimientos de Carmela de forma irreversible, puesto que la ha manipulado para gozar de ella a costa de su honor; se ha servido del engaño para atentar contra su libertad y contra sus deseos, porque Carmela jamás le hubiese dado su consentimiento de haber conocido la verdad; que se quiera suicidar al descubrirlo todo es la prueba de ello. El hecho de que Martínez Colomer atribuya infamias de este calibre a los seguidores de Rousseau y demás filósofos es, de nuevo, una forma de emplear cierta clase de sensacionalismo truculento para difamar la filosofía de la Ilustración.

En la filosofía del ginebrino y de los otros autores mencionados en la novela pueden tener lugar muchos juicios contrarios a los dogmas católicos, pero de ninguna manera se pueden inferir de sus textos consideraciones tan terribles como las que Martínez Colomer insinúa, esto es, que abusar de la inocencia de las personas es algo moralmente aceptable ${ }^{46}$; no obstante, convertir al seguidor

46. Sin embargo, juicios semejantes son esgrimidos por los libertinos del marqués de Sade en, por ejemplo, Justina o los infortunios de la virtud; según la filosofía que Sade pone en boca de sus personajes, completamente materialista, ninguna transgresión debe ser tenida por inmoral, ni siquiera la violación o el asesinato. Si Martínez Colomer se escandalizaba al leer a autores como Rousseau, 
de Rousseau en alguien profundamente malvado habrá de provocar en el lector, necesariamente, la falsa impresión de que la filosofía del ginebrino es algo puramente maligno que no habrá de causar más que daño y prejuicios en la sociedad.

Es especialmente curioso que sea el sensacionalismo lo que, indirectamente, haya permitido a Martínez Colomer el lograr uno de los principales aciertos de esta novela: hablamos de la sensibilidad con la que trata el tema de la muerte. A pesar de que el autor no tenga otra intención que la de asustar al lector, todo lo relativo al fin de la vida es tratado en esta narración de una manera poco habitual en la narrativa española anterior; nos referimos a la angustia y a la desesperación del que va a morir sin el consuelo del más allá. Aunque la intención de Martínez Colomer sea, precisamente, hacer ver al público que no hay motivo de desesperación para aquel que se mantenga fiel a la Iglesia, resulta necesario mostrar al detalle toda esa angustia para hacer comprender a qué clase de horrores se enfrentan los impíos que osan ir contra el dogma católico. El autor es alguien reaccionario que detesta la filosofía de su tiempo, pero que no por ello es menos consecuente con la nueva sensibilidad de su época; en un afán de atacarla, acaba mostrándola con todo lujo de detalles. Curiosamente, aparecerá una angustia similar con respecto al tema de la muerte en ciertos románticos europeos a los que, indirectamente, Martínez Colomer se está acercando. Pensemos, si no, en Jean Paul, más o menos contemporáneo al autor de El impio: «No le cierres nunca más los ojos a un difunto, porque los párpados después se pudren, y es entonces cuando ve: ve que ya no hay Dios... ¡Oh, felices vosotros, los que estáis vivos! ${ }^{47}$. Ideas idénticas aparecerán en Percy Shelley, con su ensayo Sobre un estado futuro, al que Martínez Colomer se estaría anticipando relativamente: "El deseo de ser para siempre lo que somos; la resistencia a un cambio violento y jamás experimentado, que es común a todas las combinaciones animadas e inanimadas del universo, es, sin duda, la secreta convicción que ha originado la creencia en un estado futuro ${ }^{48}$.

Estas ideas son las que ya subyacen en la novela de Martínez Colomer, en la que la muerte acaba siendo el tema principal. Aquí se ve, en el personaje de don Paco, la angustia del que va a morir y se enfrenta a ese "cambio violento y jamás

\footnotetext{
Voltaire o Helvétius, su reacción de haber leído a Sade hubiese sido inimaginable; pero teniendo en cuenta que Sade era un gran admirador de Rousseau y Voltaire, la sola existencia de una persona como el divino marqués hubiese servido de pretexto para que Martínez Colomer persistiera en su idea de que los intelectuales ilustrados son los heraldos de la atrocidad moral. Es preciso señalar que, curiosamente, en los libertinos de ambas novelas se está dando una problemática que ya fue advertida por d'Holbach: "Por otro lado, ¿no es peligroso ligar la moral con la religión? En lugar de apuntalar la moral, ¿no es darle un apoyo débil y ruinoso querer fundarla sobre la religión? [...] Es así como a menudo, después de haber sacudido el yugo de la religión, vemos a hombres perversos entregarse al libertinaje, a la desmesura, al crimen» (Holbach, Barón d'. El cristianismo desenmascarado. 1. ${ }^{a}$ edición en castellano. Madrid: Valdemar, 2017, pp. 142-143).

47. Paul, Jean. Alba del nibilismo. 1. ${ }^{a}$ edición. Madrid: Akal, 2005, p. 35.

48. SHelley, Percy B. Crítica filosófica y literaria. 1. ${ }^{\text {a }}$ edición. Madrid: Akal, 2002, p. 82.
} 
experimentado»; y en el personaje de Eugenio, ese ímpetu irracional que, motivado por "el deseo de ser para siempre lo que somos", acaba rechazando el saber empírico en favor de la fe en los misterios de la religión, en esa «secreta convicción que ha originado la creencia en un estado futuro". El pasaje de la muerte de don Paco acaba siendo, con bastante diferencia, lo más trabajado y meritorio de toda la obra, y ahí podemos encontrar un despliegue de sentimientos singular, un lirismo concentrado que transmite toda clase de sensaciones: angustia, violencia, y un terror sublime ante el espanto de concluir con el estado conocido y arrojarse o bien a la nada, o bien al tribunal de un Dios furibundo que ha sido ofendido por la vanidad del impío.

El resto de los elementos de la novela no son más que la preparación del terreno para ese pasaje final. La sátira costumbrista y francófoba o el sermón moral habido en la discusión de Eugenio con don Paco son elementos que, aunque puedan resultar interesantes, no tienen de ningún modo un papel protagonista en la obra. Lo satírico y lo moral, de hecho, propician el tratamiento de la muerte con esa sensibilidad renovadora y burkeana; el pasaje del final acaba trascendiendo toda crítica social al expresar una serie de preocupaciones trascendentales que habrían de azotar a todos los seres humanos de la Edad Contemporánea, desde la época de Martínez Colomer hasta nuestros días.

\section{UNA GENERACIÓN DE «IMPÍOS POR VANIDAD»}

Una novela de semejantes características, repleta de dogmatismo, prejuicios y tergiversaciones, nos podría llevar a concebir a Martínez Colomer como un sujeto especialmente reaccionario; con todo, es menester señalar que esa actitud era, en cierta medida, una constante entre los intelectuales de la época, incluyendo a los novelistas. Es más: El impío por vanidad habría de ser la primera de un notable grupo de novelas que reproducirían, más o menos, las mismas características: todas ellas están protagonizadas por afrancesados que, influidos por la vertiente más heterodoxa de la Ilustración, acaban chocando con los valores tradicionalistas de la Iglesia católica, al igual que don Paco. La primera de todas estas fue, claramente, El Evangelio en triunfo de Pablo de Olavide (1798). El argumento es muy parecido al de El impio por vanidad: nos cuenta la historia de un libertino afrancesado que, después de leer a muchos de los filósofos de la Ilustración, acaba teniendo una conducta impía e irreligiosa; poco después tiene un encuentro con un personaje cristiano de gran religiosidad, muy similar a Eugenio, que acabará rebatiéndole toda la filosofía en la que cree. No obstante, hay ciertas variaciones en el argumento, ya que en este caso el religioso acaba desengañándolo de toda su filosofía y consiguiendo su reconversión al cristianismo. En cualquier caso, la novela de Olavide tuvo muchísimo más éxito que la de Martínez Colomer, ya que 
llegó incluso a aparecer, traducida, en el extranjero, y se siguió reeditando hasta llegar a nuestros días ${ }^{49}$.

La siguiente de estas obras se publicó en 1814, y se tituló El liberal en Cádiz o aventuras del abate Zamponi, de Ramón Valdivares y Longo. En ella hay un ataque no solo a los afrancesados, sino también a los pertenecientes al bando liberal, quienes son acusados de gran impiedad; el protagonista es un sujeto estrafalario, a caballo entre don Quijote y fray Gerundio, que pretende instruirse en los principios filosóficos de los liberales, aunque ello suponga un ataque a su religión. El tono de la obra, no obstante, es mucho más ridículo que el de El impío por vanidad o El Evangelio en triunfo, pero las ideas son más o menos similares, y su protagonista también acaba chocando con un religioso que intenta poner freno a su filosofía.

Del mismo año es también el primer tomo de una obra que no se publicaría entera hasta más tarde: nos referimos al Don Papis de Bobadilla de Rafael José de Crespo $^{50}$. El protagonista es un sujeto más ridículo aún, claro trasunto de don Quijote; un individuo alucinado con la lectura de filósofos irreligiosos, que pretende recorrer el mundo para propagar sus ideas contrarias al cristianismo y librar al mundo de la religión. Semejante actitud es identificada no especialmente con la impiedad, sino más bien con la locura; de esta forma, ateos y deístas son tachados de tener poca cordura por pretender cuestionarse la existencia del Dios cristiano.

Nueve años después aparece una nueva narración muy similar, quizá más interesante desde el punto de vista literario que las cuatro anteriores: Historia del valeroso caballero don Rodrigo de Peñadura, de Luis Arias de León. Don Rodrigo es «un hidalgo de mala muerte» que, «a fuerza de leer los delirios del contrato social y los disparates de que abundan las obras del filósofo de Ferney, se le llegó a resecar el cerebro hasta tal punto que los médicos declararon hallarse muy expuesto a un ataque de demencia "s1. Los paralelismos con el Don Papis de Bobadilla son más que evidentes; no obstante, esta narración quizá sea una de las más divertidas de todas las que surgieron en la línea de El impío por vanidad, porque la moralización desparece casi del todo en favor de un sinfín de escenas disparatadas y ridículas.

La producción de este tipo de narraciones se alargó, incluso, unos años más. Así, en 1827 se publica El secreto revelado en cartas confidenciales, que un

49. La edición que hemos manejado, de hecho, es de 2004; para un informe algo más detallado del éxito de la novela de Olavide, véase la introducción a esa misma edición (GÓmEz URDÁÑEz, José Luis. «Introducción». En Olavide, Pablo de. El Evangelio en triunfo o bistoria de un filósofo desengañado [2 vols.]. 1. ${ }^{a}$ edición [1. ${ }^{a}$ edición en castellano: 1798]. Oviedo: Pentalfa, 2014, p. 25).

50. Álvarez de Miranda, Pedro. "La primitiva versión (1814) del Don Papis de Bobadilla de Rafael José de Crespo». En CARNERO, Guillermo; LóPEZ, Ignacio Javier y RuBio, Enrique. Ideas en sus paisajes. Homenaje al profesor Russell P. Sebold. 1. ${ }^{a}$ edición. Alicante: Universidad, 1999, pp. 63-70.

51. ARIAS DE LEÓN, Luis. Historia del valeroso caballero don Rodrigo de Peñadura. 1. a edición [1. ${ }^{a}$ edición original: 1823]. León: Edilesa, 2007, p. 21. 
constitucional rezagado escribía a sus amigos refugiados en Londres, reconviniéndoles por los graves yerros que han cometido, y dándoles instrucciones seguras para su final enmienda; novela moralizante, algo farragosa, cuyo extenso título, según consideramos, explica más que de sobra su contenido. De la misma fecha, pero bastante mejor conseguida, es Voyleano o la exaltación de las pasiones, de Estanislao de Cosca Vayo; en ella el héroe principal es nuevamente un libertino afrancesado que acaba siendo reprendido por un católico, y que guarda similitudes muy notables con don Paco, aunque al final acaba convirtiéndose a los valores tradicionalistas. Todo ello con el escenario de la guerra de la Independencia de fondo, lo cual permite una singular conclusión, con el protagonista dando la vida por su patria y por rechazar a los franceses.

En 1829 se terminaron de publicar los tomos restantes del Don Papis de Bobadilla; un total de seis. Como conjunto, la novela quizá sea demasiado extensa e insistente en el terreno de la moralización; recuerda bastante, en ese sentido, a El Evangelio en triunfo. El protagonista, al final de la obra, también acaba cristianizándose al darse cuenta de lo supuestamente inconsistente que es la filosofía ilustrada más heterodoxa.

Al margen del interés que pudiesen tener o dejar de tener todas estas novelas, su existencia nos permite comprender que El impío inauguró lo que habría de convertirse en toda una tendencia novelística en nuestro país durante una época llena de actitudes reaccionarias, en la que los novelistas no solían priorizar las pretensiones literarias. Por tanto, se ha de tener en cuenta la figura de Martínez Colomer como referente de algo que habría de ser habitual: un sujeto católico, tradicionalista y enemigo ferviente de toda doctrina heterodoxa, que encuentra en la novela un arma eficaz con la que atacar toda la nueva filosofía que vendría a amenazar los cimientos sobre los que está establecida la moral del cristianismo.

\section{CONCLUSIÓN}

El impio por vanidad es, ante todo, propaganda religiosa; bien elaborada, y con un cuidadoso empleo de lo sentimental, pero propaganda. Su autor, aparentemente, no conoce demasiado bien a los filósofos a los que está criticando ${ }^{52}$; tampoco lo necesita, puesto que se dirige a un público que supuestamente debería tener aún menos conocimientos en la materia. Es más: uno de sus principales objetivos era lograr que sus potenciales lectores huyeran a toda costa de las obras de los filósofos que son atacados. Si tenemos en cuenta que en la España de la época estaban prohibidas las obras de autores como Rousseau, no resultaba demasiado difícil evitarlos; es lógico afirmar, incluso, que muchos españoles de finales del

52. Cabe también la posibilidad de que su conocimiento sea mayor del que demuestra; en tal caso, estaría tergiversando a propósito la filosofía de estos autores para presentarla al público como algo más deplorable. 
XVIII solo tenían noticia de la filosofía de esos autores a través de obras como la de Martínez Colomer, en las que se difama y se demoniza algo que previamente estaba prohibido.

El sentimentalismo que pueda haber en esta novela está estrictamente ligado al afán sensacionalista del autor, que se dirige a un público católico, ingenuo y fácil de escandalizar; un público, en definitiva, capaz de atemorizarse incluso ante la existencia de esos supuestos "depravados" que negaban la existencia de Dios. Y, al parecer, logró medianamente sus objetivos, no solo porque esta obra gozó de algo de éxito ${ }^{53}$, sino también porque, como ya hemos visto, tras esta novela vinieron otras tantas de características similares, lo cual vendría a evidenciar una clara postura ideológica y religiosa por parte de los autores y lectores de novelas en la España de la época.

Martínez Colomer, por lo general, ha sido estudiado y reconocido como uno de los precursores del Romanticismo en nuestro país en el terreno de la novela; no obstante, creemos que quizá pueda tener cierto interés destacar también su faceta como propagandista, en tanto que fue pionero de esta clase de reaccionarismo en el género novelesco. Pese a que El impío por vanidad no sea su mejor obra, consideramos que debe ser tenida en cuenta como evidente testimonio de la ideología de la España más conservadora ante el imparable avance de las ideas más radicales de la Ilustración, cuyo resultado más evidente, la Revolución francesa, modificó para siempre la sociedad tal y como hasta ese momento se conocía.

\section{BiBLIOGRAFÍA}

ALMEIDA, Teodoro de. El hombre feliz. 1. a edición. [1. ${ }^{a}$ edición en castellano: 1783]. Madrid: Yatay, 1998.

Álvarez DE Miranda, Pedro. «El padre Andrés Merino, autor de la monarquía columbina». En ETIENVRe, Jean Pierre (coord.). Las utopias en el mundo hispánico: actas del coloquio celebrado en la Casa de Velázquez. 1. a edición. Madrid: Editorial Complutense, 1990, pp. 19-40.

Álvarez De Miranda, Pedro. «La primitiva versión (1814) del Don Papis de Bobadilla de Rafael José de Crespo». En CARNERO, Guillermo; LóPEz, Ignacio Javier y RuBIO, Enrique (eds.). Ideas en sus paisajes. Homenaje al profesor Russell P. Sebold. 1. ${ }^{a}$ edición. Alicante: Universidad, 1999, pp. 63-70.

Álvarez Barrientos, Joaquín. La novela del siglo XVIII. 1. a edición. Madrid: Júcar, 1991.

ÁLVAREZ BARRIENTOS, Joaquín. "Imagen francesa y civilización en la novela del siglo XVIII». En AYMES, Jean-René (coord.). La imagen de Francia en España durante la segunda


de Cultura Juan Gil Albert, 1996, pp. 167-176.

53. Recordemos su reedición en el conjunto de las Novelas morales, colección que, a su vez, tuvo al menos una segunda edición años más tarde (Diario de Madrid, 13 de agosto de 1839, p. 2d). 
ARIAS DE LEÓN, Luis. Historia del valeroso caballero don Rodrigo de Peñadura. 1. ${ }^{a}$ edición [1. ${ }^{a}$ edición original: 1823]. León: Edilesa, 2007.

ARMiÑo, Mauro. «Introducción». En RousseAu, Jean-Jacques. Las ensoñaciones del paseante solitario. 3. ${ }^{\mathrm{a}}$ edición. Madrid: Alianza, 2016, pp. 9-43.

BAYle, Pierre. La católica Francia. 1. ${ }^{a}$ edición en castellano. Madrid: Ediciones del Laberinto, 2000.

BROwn, Reginald F. La novela española 1700-1850. 1. a edición. Madrid: Dirección General de Archivos y Bibliotecas, 1953.

Burke, Edmund. De lo sublime y lo bello. $2 .^{a}$ edición [1. ${ }^{a}$ edición en castellano: 1807]. Madrid: Alianza, 2014.

CARnero, Guillermo. «Introducción». En Martínez Colomer, Vicente. El Valdemaro. $1 .^{a}$ edición [1. ${ }^{\mathrm{a}}$ edición original: 1792]. Alicante: Instituto de Estudios Juan Gil Albert, 1985, pp. 9-47.

CARNERO, Guillermo. Estudios sobre narrativa y otros temas dieciochescos. 1. a edición. Salamanca: Universidad de Salamanca, 2009.

Condillac, Étienne Bonnot de. Lógica. Extracto razonado del Tratado de las sensaciones. 1. ${ }^{a}$ edición [1. ${ }^{a}$ edición de la Lógica: 1784]. Barcelona: Orbis, 1982.

Cruz, Ramón de la. Sainetes. 3. ${ }^{a}$ edición. Madrid: Aguilar, 1964.

Delgado, Jacinto María. Adiciones a la historia del ingenioso hidalgo Don Quijote de la Mancha, en que se prosiguen los sucesos ocurridos a su escudero el famoso Sancho Panza. $1 .^{\mathrm{a}}$ reimpresión mexicana [1. ${ }^{\mathrm{a}}$ edición original: 1786]. México: Imprenta del ciudadano Santiago Ferez, 1842.

Ekome BiYogo, Gertrude. «El espacio y la construcción del mensaje ético en las Novelas morales de Vicente Martínez Colomer». Espéculo. Revista de Estudios Literarios, 2010-2011, 46, p. 43.

FERNÁNDEZ DE LIZARDI, José Joaquín. El Periquillo Sarniento. $1 .^{a}$ edición [1. a edición original: 1816]. Madrid: Cátedra, 1997.

García Malo, Ignacio. Voz de la naturaleza. $1 .^{a}$ edición a cargo de Guillermo Carnero [1. ${ }^{a}$ edición original: 1787-1803]. Madrid: Támesis, 1995.

GIL Novales, Alberto. "Burke en España». En II Simposio sobre el padre Feijoo y su siglo (Ponencias y comunicaciones). 1. ${ }^{a}$ edición. Oviedo: Centro de estudios del S. XVIII, 1981, pp. 63-75.

GOETHE, Johann Wolfgang von. Las desventuras del joven Werther. 21. ${ }^{a}$ edición $\left[1 .{ }^{a}\right.$ edición en castellano: 1835]. Madrid: Cátedra, 2012.

Gómez URdáÑEz, José Luis. «Introducción». En Olavide, Pablo de. El Evangelio en triunfo o historia de un filósofo desengañado (2 vols.). 1. ${ }^{a}$ edición [1. ${ }^{a}$ edición en castellano: 1798]. Oviedo: Pentalfa, 2004, pp. 9-26.

HeLvÉTIUS (Claude-Adrien Schweitzer). Del espíritu. 2. ${ }^{a}$ edición [1. ${ }^{a}$ edición en castellano: 1984]. Pamplona: Laetoli, 2016.

HERRERO, Javier. Los orígenes del pensamiento reaccionario español. 1. ${ }^{a}$ edición. Madrid: Alianza, 1988.

Holbach, Barón d'. El cristianismo desenmascarado. 1. ${ }^{a}$ edición en castellano. Madrid: Valdemar, 2017.

Lafarga, Barón d' y Pegenaute, Luis. Diccionario histórico de la traducción en España. 1. ${ }^{\circledR}$ edición. Madrid: Gredos, 2009.

MarTín Gaite, Carmen. Usos amorosos del dieciocho en España. 1. ${ }^{a}$ edición $\left[1 .{ }^{a}\right.$ edición en castellano: 1973]. Madrid: Siruela, 2017. 
Martínez Colomer, Vicente. El impío por vanidad. ¿1. ${ }^{a}$ edición? Valencia: Josef Estevan, 1795.

MarTínez Colomer, Vicente. Novelas morales. 2. ${ }^{\text {a }}$ edición $\left[1 .^{a}\right.$ edición, sin El impío por vanidad: 1790]. Valencia: Benito Monfort, 1804.

MARTínez Colomer, Vicente. El Valdemaro. $1{ }^{a}{ }^{a}$ edición [1. ${ }^{a}$ edición en castellano: 1792]. Alicante: Instituto de Estudios Juan Gil Albert, 1985.

Martínez Colomer, Vicente. Los trabajos de Narciso y Filomela. Una novela cervantina del siglo XVIII. 1. ${ }^{\text {a }}$ edición de un texto inédito del XVIII, a cargo de Antonio Cruz Casado. Córdoba: Diputación, 2000.

MenÉNDeZ Pelayo, Marcelino. Historia de los heterodoxos españoles (2 vols.). 2. ${ }^{a}$ edición [1. ${ }^{a}$ edición original: 1880-1882]. Madrid: La Editorial Católica, 1956.

MERINO De JesucRISTO, Andrés. La mujer feliz, dependiente del mundo y de la fortuna (3 vols.). 3. ${ }^{\mathrm{a}}$ edición. Madrid: Imprenta real, 1789.

MERINO DE JESUCRISTO, Andrés. Tratado sobre la monarquía columbina. $1 .^{a}$ edición de un texto inédito del XVIII, a cargo de Pedro Álvarez de Miranda. Madrid: El Archipiélago, 1980.

MONTESINOS, José F. Introducción a una historia de la novela en España en el siglo XIX. 1. ${ }^{\mathrm{a}}$ edición [1. ${ }^{a}$ edición original: 1955]. Madrid: Castalia, 1982.

OGANDO GONZÁLEZ, Iolanda. "La literatura portuguesa del siglo XVIII: ostentación, razón, modernidad». En Fernández García, María Jesús (coord.). Historia de la literatura portuguesa. 1. ${ }^{a}$ edición. Mérida: Junta de Extremadura, 2011, pp. 175-189.

Olavide, Pablo de. El Evangelio en triunfo o historia de un filósofo desengañado. 1. a edición [1. ${ }^{a}$ edición original: 1798]. Oviedo: Pentalfa, 2004.

PALACIOS FERNÁNDEZ, Emilio. "El padre Andrés Merino de Jesucristo y la cultura española del siglo XVIII". Boletín de la Real Sociedad Bascongada de Amigos del País, 1991, 47 (1), pp. 3-42.

PAUL, Jean. Alba del nihilismo. 1. ${ }^{\text {a }}$ edición. Madrid: Akal, 2005.

Pinilla, Juan y LePInETTE, Brigitte. Alba del nihilismo. 1. ${ }^{a}$ edición. Madrid: Akal, 2005.

Richardson, Samuel. Clara Harlowe (9 vols.). 2. ${ }^{a}$ edición. Madrid: Imprenta que fue de Fuentenebro (tomos 1, 6 y 9), Repullés (tomos 2, 4 y 8) y Verges (tomos 3, 5 y 7), 1829.

Rousseau, Jean-Jacques. Del contrato social. Sobre las ciencias y las artes. Sobre el origen $y$ los fundamentos de la desigualdad entre los hombres. 1. ${ }^{a}$ edición, 7. ${ }^{a}$ reimpresión [Primeras ediciones en castellano: 1799 (Del contrato social), 1909 (Discurso sobre las ciencias y las artes), 1820 (Sobre el origen y los fundamentos de la desigualdad entre los hombres)]. Madrid: Alianza, 1990.

Rousseau, Jean-Jacques. La nueva Eloísa. $1 .^{a}$ edición [1. ${ }^{a}$ edición en castellano: 1814]. Madrid: Cátedra, 2013.

Rousseau, Jean-Jacques. Las ensoñaciones del paseante solitario. $3 .^{a}$ edición [1. ${ }^{a}$ edición en castellano: 1916]. Madrid: Alianza, 2016.

Rousseau, Jean-Jacques. Emilio o De la educación. 3. ${ }^{a}$ edición, 3. ${ }^{a}$ reimpresión $\left[1 .{ }^{a}\right.$ edición en castellano: 1817]. Madrid: Alianza, 2017.

SADE, Marqués de. Ideas sobre la novela. $1 .^{\mathrm{a}}$ edición en castellano. Barcelona: Anagrama, 1970.

SADE, Marqués de. Justina o los infortunios de la virtud. $10 .^{a}$ edición $\left[1 .^{a}\right.$ edición en castellano: 1976]. Madrid: Cátedra, 2010. 
SANTOS ZAS, Margarita. "De Zaïre de Voltaire a Xayra de García de la Huerta». En VV. AA. Homenaxe ó profesor Camilo Flores. 1. ${ }^{a}$ edición. Santiago: Servicio de Publicación de la Universidad de Santiago de Compostela, 1999, pp. 457-479.

Shelley, Percy B. Crítica filosófica y literaria. 1. a edición. Madrid: Akal, 2002, p. 82.

VALDIVARES y LONGO, fray Ramón. El liberal en Cádiz o aventuras del Abate Zamponi. Fábula épica para remedio de locos y preservativo de cuerdos. 1. ${ }^{a}$ edición [1. ${ }^{a}$ edición original: 1814]. Cádiz: Diputación, 2008.

VAYO, Estanislao de Cosca. Voyleano o la exaltación de las pasiones. $1 .^{a}$ edición $\left[1 .{ }^{a}\right.$ edición original: 1827]. Salamanca: Delirio, 2007.

VÁzQuEz, Lydia. «Introducción». En Rousseau, Jean-Jacques. La nueva Eloísa. 1. ${ }^{a}$ edición [1. ${ }^{a}$ edición original: 1813]. Madrid: Cátedra, 2013, pp. 9-110.

[VOLTAIRE (François-Marie Arouet)]. La fe triunfante del amor y cetro, o Xayra. 1. a edición. Segovia: Imprenta de don Antonio Espinosa, 1790. 